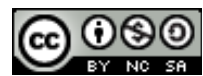

https://doi.org/10.31743/abmk.12440

\title{
DOKUMENTY I DYPLOMY KLASZTORU KLARYSEK W GNIEŹNIE. SPOSOBY UWIERZYTELNIANIA DOKUMENTÓW W PRAKTYCE KANCELARYJNEJ KONWENTU ŚW. KLARY. INWENTARZ
}

\begin{abstract}
Streszczenie
Celem artykułu jest prezentacja oraz analiza oryginalnych akt i dyplomów pergaminowych klarysek gnieźnieńskich znajdujących się w zasobie Archiwum Archidiecezjalnego w Gnieźnie pod kątem praktyki kancelaryjnej wypracowanej przez stulecia w klasztorze. Przedmiotem zainteresowania był także sposób uwierzytelniania dokumentów oraz problematyka piśmienności samych zakonnic. Kwerendą objęto dyplomy pergaminowe ze zbioru Dyplomy Gnieźnieńskie oraz dokumenty pomieszczone w zespole Akta Kapituły Metropolitalnej seria Luzy Zakon Klarysek (A Cap. Luzy O 14-52). To ponad 2500 jednostek i ponad 4000 kart. Wyselekcjonowano 161 oryginałów, w tym 3 dyplomy pergaminowe. Wszystkie zostały umieszczone w Aneksie do artykułu. Dokumenty były uwierzytelniane podpisami i/lub odbiciem tłoka pieczętnego przez papier lub na papierze. Zachowały się dwa typy - jeden o kształcie ostroowalnym, wskazujący na jego średniowieczną proweniencję, analogiczny do znanych z publikacji tłoków pieczętnych innych klasztorów żeńskich, m.in. klarysek w Skale i Krakowie. Drugi typ to tłok okrągły, który zaczął być stosowany na dokumentach wspólnoty od drugiej dekady XVIII stulecia. Językiem dominującym dokumentów jest polski, ponadto zdarzają się pojedyncze akta sporządzone w języku łacińskim - to głównie listy do osób duchownych, rzadziej świeckich. Wyróżniono 8 rzeczowych kategorii akt: kontrakty, które stanowią największą część zbioru - 77, ugody - 25, nadania - 16, listy -11 , potwierdzenia -8 , poświadczenia -7 , zezwolenia -7 oraz inne -10 . Zostały one uwierzytelnione przez 31 ksień. Jak wynika z analizy duktów pisma, dwie przełożone z XVII stulecia przygotowały pojedyncze akta własnoręcznie. Natomiast z kolejnego stulecia pochodzi siedem takich przykładów, w XIX wieku
\end{abstract}

* Olga Miriam Przybyłowicz - dr historii, adiunkt w Instytucie Archeologii i Etnologii, PolskaAkademia Nauk

e-mail: olgamiriam@interia.pl

https://oricd.org/0000-0003-3422-550X 
zaś ksieni sporządziła jeden dokument. W XVIII wieku niektóre dokumenty wystawiła też siostra sprawująca urząd sekretarki, a w jednym przypadku dukt pisma wskazuje na szeregową zakonnicę (1762). Należy przypuszczać, że większość dokumentów wspólnoty przygotowywali pisarze publiczni bądź urzędnicy klasztoru, np. prokuratorzy dóbr lub też franciszkanie z pobliskiego konwentu gnieźnieńskiego, z którymi klaryski były w dobrych relacjach, jak wynika $\mathrm{z}$ treści akt i klasztoru i prowincji.

Słowa kluczowe: klaryski; Gniezno; pergaminy; dyplomy; dokumentacja; archiwalia; inwentarz

\section{Wstęp}

W Archiwum Archidiecezjalnym w Gnieźnie (dalej: AAG) znajduje się bogaty zbiór archiwaliów obejmujący dyplomy, rękopisy, akta luźne konwentu klarysek w Gnieźnie ${ }^{1}$. Klasztor założony przed 1284 r., istniał in situ ponad 550 lat do momentu formalnej kasaty przez władze pruskie w styczniu 1837 r., choć de facto egzystencję wspólnoty zakończyła dopiero 16 stycznia 1865 r. śmierć ostatniej zakonnicy Rozalii Tekli Cywińskiej².

Spośród nich najliczniejszą grupę stanowi podseria w zespole Akta Kapituły Metropolitalnej (dalej: A. Cap.) Luzy - Zakon Klarysek (Luzy O 14-52). Zawiera ona blisko 2500 dokumentów i ponad 4000 kart w 39 jednostkach ${ }^{3}$. Trudno uznać

${ }^{1}$ O.M. Przybyłowicz, Źródta rękopiśmienne z klasztoru klarysek gnieźnieńskich w Archiwum Archidiecezjalnym Gnieźnie. Stan wiedzy, prezentacja spuścizny i możliwości badawcze, „Archiwa, Biblioteki, Muzea Kościelne" (dalej: ABMK), 112 (2019) s. 317-336. Nie zachowały się żadne źródła świadczące o fundacji za życia Bolesława Pobożnego (†1279), ale mimo to w literaturze przedmiotu częściej wspomina się o tym księciu, a nie o bratanku Przemyśle II, który uposażył fundację dobrami ziemskimi, K. Ney, Kronika zakonnic klasztoru św. Klary w Gnieźnie i żywot Jolanty, Leszno 1843; W. Sawicki, Błogostawiona Jolenta: życia i dzieje kultu, Niepokalanów 1980, s. 15 i nn.; G. Chmarzyński, w: Dzieje Gniezna, red. J. Topolski, Poznań 1976, s. 233; A. Karwacki, Materiaty do historii konwentów franciszkańskich Prowincji Polskiej, t. 9, Essen-Gdańsk 1999, s. 178, mps w Archiwum Franciszkanów w Krakowie (dalej: AFKrak.). Za Przemysłem II jako fundatorem M. Michalski, Błogosławiona Jolenta - refleksja historyczno-hagiograficzno-historiozoficzna, w: Franciszkanie konwentualni i klaryski w Wielkopolsce od XIII do XIX wieku, red. T. Janiak, D. Stryniak, Gniezno, s. 71-82, tu s. 75; O.M. Przybyłowicz, Reguła zakonna jest wozem do nieba. Realia życia w klasztorach klarysek w Małopolsce, Wielkopolsce i na Śląsu, Warszawa 2016, s. 31 i nn; Dokument Przemysła II, Kodeks dyplomatyczny Wielkopolski (dalej: KDW), wyd. I. Zakrzewski, Poznań 1877, nr 550. O reskryptach kasacyjnych Z. Joskowski, Katalog starych druków biblioteki franciszkanów w Gnieźnie, Banino 2015, s. 6,10.

${ }^{2}$ M. Borkowska, Leksykon zakonnic polskich epoki przedrozbiorowej, t. 1: Polska Zachodnia i Pólnocna, Warszawa 2004, s. 38. Rozalia (Tekla - kursywą zawsze imię zakonne) Cywińska, s. 38. Nieznane Borkowskiej informacje w innych źródłach, m.in. Aktach Luźnych. Np. Cywińska była także przez 29 lat zakrystianką, dziewięć kanafarką, zaś furtianką i depozytarką dwa lata, AAG, A. Cap. Luzy O 16 k. 6. W niniejszym tekście podaję jednak informacje za M. Borkowską, nie korygując jej informacji, co czynię natomiast w Aneksie tylko w odniesieniu do ksień, uznając za podstawę informacji przygotowywany artykuł o przełożonych wspólnoty gnieźnieńskiej w XVI-XIX wieku.

${ }^{3}$ Przejrzenie i selekcji takiej ilości akt nie byłoby możliwe bez życzliwości pracowników archiwum, za co składam im podziękowania. Charakterystyka archiwaliów klarysek: O.M. Przybyło- 
te archiwalia za „relikty klasztorne”, jak wspominali o wszystkich poklasztornych materiałach (nie tylko klarysek) badacze piszący przed laty o zasobie archiwum Jednostki odnoszące się do dziejów wspólnoty Ubogich Panien o liczbie porządkowej 14-52 ze zbioru AAG A. Cap. Luzy Zakon Klarysek dotyczą tematycznych grup wydzielonych przez archiwistów jeszcze pod koniec XIX wieku. Osobnym jednostką pomieszczoną w zespole AAG A. Cap. II jest podseria o numerze 865: Renowacja kaplicy klarysek 1766-1785 oraz jednostki znajdujące się w zespole AAG Dyplomy Gnieźnieńskie.

Z tych wszystkich zespołów i podserii wyselekcjonowałam wyłącznie oryginały. Najistotniejszym kryterium wyboru była osoba wystawcy - klasztor. Mógł być on reprezentowany przez: ksienię i konwent, samą przełożoną występującą w imieniu sióstr bądź swoim, pełnomocnika wspólnoty lub jedną z zakonnic. Zgromadziłam i sklasyfikowałam 158 dokumentów papierowych klarysek z XVI-XVIII wieku oraz trzy pergaminowe - w sumie prezentowany inwentarz to 161 akt.

W podserii zespołu AAG A. Cap. Luzy O 14-52 znajduje się też wiele dokumentów powstałych najprawdopodobniej w klasztorze, pod którymi nie ma podpisów zakonnic, są natomiast autografy drugiej strony, np. osób świeckich zawierających umowę lub kontrakt ze wspólnotą ${ }^{5}$ Takie archiwalia nie zostały uwzględnione w niniejszej analizie i Aneksie prezentującym spuściznę aktową klarysek. Uznałam, że brak aprobaty zakonnic świadczył o tym, iż nie doszło do ostatecznego potwierdzenia akcji prawnej przez konwent. W zestawieniu nie zamieszczono również różnego rodzaju kopii, oblat, uwierzytelnionych odpisów, ekstraktów poświadczonych w instytucjach sądów grodzkich i ziemskich pieczęciami odpowiednich urzędników, także centralnych oraz kopii nieuwierzytelnionych, ze względu na wtórny charakter takich przekazów ${ }^{6}$.

Nie zaliczałam także do badanej grupy dokumentu wystawionego w lipcu 1677 r. w Kcyni przez gwardiana franciszkanów w Gnieźnie Bernarda Pawłow-

wicz, Archiwalia klarysek gnieźnieńskich w Archiwum Archidiecezji Gnieźnieńskiej, cz. 1: Sprawozdanie z kwerendy $w$ dniach 29-31 VIII 2012 r., „Hereditas Monasteriorum” (dalej: HM), 1 (2012) s. 456-462; O.M. Przybyłowicz, Archiwalia klarysek gnieźnieńskich w Archiwum Archidiecezji Gnieźnieńskiej, cz. 2: Sprawozdanie z kwerendy w dniach 9-12 VII 2013 r., HM, 3 (2013) s. 552569.

${ }^{4}$ J. Korytkowski, Prałaci i kanonicy katedry metropolitalnej od 1000 roku aż do dni naszych podtug źródet archiwalnych, t. 1, Gniezno 1883, rozdz. 6: Obowiązi kapituły, c. Archiwum kapitulne, s. 482-501, d. Biblioteka kapitulna, s. 501-515. Kolejne kompendium części zbiorów, tym razem bibliotecznych, opracował ks. T. Trzciński, Katalog rękopisów biblioteki kapitulnej w Gnieźnie aż do początku XVI w., „Roczniki Towarzystwa Przyjaciół Nauk Poznańskiego”, 35 (1910) s. 169-320. L. Formanowicz, Katalog druków polskich XVI-go wieku Biblioteki Kapitulnej w Gnieźnie, Poznań 1930; L. Formanowicz, Katalog inkunabułów Biblioteki Kapitulnej w Gnieźnie, z. 1, Poznań 1939; J. Wojtkowski, Rekonstrukcja drugiego zeszytu katalogu inkunabułów Biblioteki Kapitulnej w Gnieźnie księdza Leona Formanowicza, Lublin 1969. J. Rył, Katalog rękopisów Biblioteki Katedralnej w Gnieźnie, ABMK, 45 (1982) s. 5-201; J. Rył, Archiwum i biblioteka w Katedrze Gnieźnieńskiej, Gniezno 1994.

${ }^{5}$ Takich dokumentów jest ponad 20.

${ }^{6}$ Dyplomatyka staropolska, red. T. Jurek, Warszawa 2015, s. 45-46. 
skiego oraz brata Kazimierza Lenartowicza, spowiednika klarysek, reprezentujących konwent per procura, którzy zawarli ugodę z osobą świecką na sprzedaż dziesięciny z ról kcyńskich za kwotę 315 zł7

Cała zgromadzona kolekcja dotyczy w przeważającej mierze spraw gospodarczych oraz - w mniejszym stopniu - spraw wewnętrznych konwentu. Analiza akt pozwala poznać praktykę wystawiania i uwierzytelniania dokumentów, ale daje też asumpt do wejrzenia w sposób funkcjonowania klauzurowej wspólnoty Ubogich Panien, w której - jak wynika ze źródeł - sprawy doczesne były traktowane niemniej poważnie niż kwestie duchowe.

W niniejszym artykule pragnę zwrócić uwagę nie na kwestie gospodarcze, które są przedmiotem moich innych analiz na podstawie różnorodnych źródeł, nie tylko aktowych, a przede wszystkim na sposób funkcjonowania dokumentu w żeńskim konwencie klauzurowym w epoce nowożytnej. Praktykę działań klarysek będę rozpatrywać nie w sferze działalności instytucji (gdyż kancelarii i urzędników kancelaryjnych w rozumieniu dyplomatyki staropolskiej w klasztorze nie było), ale jako instrument i element kontaktów wspólnoty ze światem zewnętrznym. Osobnym zagadnieniem będzie rozpoznanie jednego z aspektów wykształcenia zakonnic - stopnia alfabetyzacji począwszy od średniowiecza po XIX wiek. Ustaleń w tym względzie dokonałam na podstawie liczby podpisów poszczególnych klarysek na dokumentach oraz duktu pisma. Żadne z powyższych zagadnień nie było do tej pory przedmiotem głębszych analiz specjalistów zajmujących się problematyką monastycyzmu na ziemiach Rzeczypospolitej w dobie nowożytnej.

Dyplomy i dokumenty uwierzytelniane były przez wspólnotę - zakonnice podpisem lub podpisami oraz pieczęcią, najczęściej odbiciem tłoka pieczętnego przez papier lub na papierze. Ta druga forma stosowana była znacznie rzadziej. W kilku przypadkach, tj. najstarszych dyplomów pergaminowych, pieczęcie zawieszano pod aktem (zachowały się tylko ślady takiej praktyki w postaci otworów $\mathrm{w}$ pergaminie). W epoce nowożytnej używano dwóch rodzajów pieczęci starszej, o kształcie tłoka ostroowalnym, wskazującym na średniowieczną proweniencję. Ten krój stosowany był w Gnieźnie do uwierzytelniania dokumentów aż do początku XVIII wieku. Drugi typ, okrągły, zaczął pojawiać na dokumentach od drugiej dekady XVIII stulecia i przetrwał w dokumentacji do końca istnienia zgromadzenia. W obydwu przypadkach są to pieczęcie opłatkowe - tłoczone przez papier lub bezpośrednio na nim w wosku.

Dokumenty klarysek sygnowali też, oprócz sióstr, potwierdzając akcję prawną dokonaną przez klaryski, franciszkanie. Byli to przełożeni zakonni - ministrowie bądź ich delegaci, zakonnicy pełniący funkcje spowiedników lub prokuratorów wspólnoty. $\mathrm{Ci}$ ostatni pochodzili najczęściej z pobliskiego klasztoru w Gnieźnie (byli tam np. gwardianami). Nie wiadomo, jaka była skala takich działań. Praktykę tę można uznać za dodatkowy sposób potwierdzania woli wspólnoty. Z zachowanych archiwaliów wynika, że nie zdarzało się to zbyt często. Fakt potwierdzania akcji prawnej i decyzji sióstr przez franciszkanów z Gnie-

${ }^{7}$ AAG, A. Cap. Luzy O 28, k. 32 z podpisami obydwu stron. 
zna (Ubogie Panie dzieliły z nimi świątynię, zajmując północną nawę kościoła oddzieloną od reszty świątyni, z dwukondygnacyjnym oratorium, tj. chórem zakonnym), wskazuje na bliskie i dobre relacje obydwu konwentów. Potwierdzają to zresztą inne źródła, w tym wpisy w „Księdze wszystkich spraw Konwentu Gnieźnieńskiego zakonu S. Klary [...] pilnie pisane w roku pańskim 1609”8.

\section{Charakterystyka akt}

Najstarszy z dokumentów to dyplom wystawiony na pergaminie przez ksienię Staszkę w 1371 r., potwierdzający transakcję finansową osób świeckich dotyczącą dóbr konwentu. Został on opublikowany w Kodeksie Wielkopolskim?'. Kolejne zachowane pergaminy pochodzą już z XVII wieku - jeden z okresu rządów ksieni Doroty Bromirskiej z 1617 r. ${ }^{10}$, a drugi z 1637 r., gdy urząd przełożonej sprawowała Katarzyna Obediencja Jarkuszewska ${ }^{11}$. Na pergaminach pozostały jedynie ślady uwierzytelnienia pieczęciami - otwory po ich przywieszeniu. Niestety same odciski pieczęci wspólnoty Ubogich Pań nie zachowały się w archiwum w Gnieźnie, podobnie jak tłoki pieczętne.

157 oryginałów w AAG A. Cap. Luzy O 14-52 to wyłącznie spuścizna papierowa, podobnie jak jeden dokument pomieszczony w zespole AAG A. Cap. II 865. W grupie 158 dokumentów znalazł się jeden dość osobliwy. To kontrakt, który został podpisany przez dwie ksienie - Agatę Rozalię Łącką i Katarzynę Jolentę Wierzbińską ${ }^{12}$. Data jego wystawiania jest zbieżna z obiorem nowej przełożonej - Wierzbińskiej i zapewne tym można tłumaczyć tę sytuację. Jest to umowa na wyrób klepek i rynek z drewna pozyskanego z lasu należącego do klarysek ${ }^{13}$. Kontrakt z rzemieślnikiem Pawłem Boguńskim zawarła Łącka w 1735 r., a pod

${ }^{8} \mathrm{~W}$ średniowiecznych źródłach nie ma informacji o konfliktach czy nieporozumieniach między obydwiema wspólnotami franciszkańskimi, co zdarzało się np. w Krakowie lub Wrocławiu, Przybyłowicz, Reguła zakonna, s. 34-35, 107, 111, 283. AAG, Zakon Klarysek Gniezno, sygn. 3, „Księgi wszystkich spraw Konwentu Gnieźnieńskiego zakonu S. Klary. To jest katalog wszystkich sióstr zakonnych w tym klasztorze od pamięci ludzkiej professowanych żywych i zmarłych. Przytem inwentarz wszystkich dóbr prowentów także i przywilejów tegoż klasztoru za urzędu Wielebnej w Chrystusie Panny, Panny Doroty Bromierskiej, na ten czas Ksieniej tegoż klasztoru (acz niegodnej) uczynione, i pilnie pisane w roku pańskim 1609" (dalej: Księgi 1609).

${ }^{9}$ AAG, Dyplomy Gn. nr 191. Ksieni Staszka poświadcza, iż Arnold mieszczanin gnieźnieński z siostrami Małgorzatą i Krystyną sprzedał Goczkowi, wójtowi gnieźnieńskiemu, sołectwo w Woźnikach, edycja w: KDW, t. 3, nr 1647.

${ }^{10}$ AAG, Dyplomy Gn. nr 867. Ksieni Dorota Bromirska (tu błędnie Bramirska) wraz z całym konwentem nadają pod pewnymi warunkami Wojciechowi Płotce dwa młyny - w Piszczu i w Korzeczniku.

${ }^{11}$ AAG, Dyplomy Gn. nr 886. Ksieni wraz z konwentem, w tym sześcioma wymienionymi zakonnicami nadaje Adamowi Rajowi sołectwo w Woźnikach. Podpisy sześciu zakonnic, zob. Aneks.

${ }^{12}$ AAG, A. Cap. Luzy O 33, k. 49 z 1736 r. Wliczam go do statystyk akt obydwu ksień, Borkowska, Leksykon, s. 34 o Łąckiej i Wierzbińskiej - ta druga była ksienią w latach 1736-1738.

${ }^{13}$ Klepki to dębowe deseczki-deszczułki do wyrobu naczyń, a rynka to rodzaj naczynia, Kartoteka słownika języka polskiego XVII i 1. połowy XVIII wieku (dostęp: 25.06.2019). Stownik Staropolski, t. 3, Wrocław-Kraków-Warszawa 1960-1962, s. 286. 
rozliczeniem tegoż podpisały się obydwie ksienie w maju roku następnego. W marcu 1737 r. odbiór pieniędzy i całkowite rozliczenie umowy z Boguńskim kwitowała już sama Wierzbińska.

W sumie przełożone same i w imieniu wspólnoty wystawiły 160 dokumentów papierowych, w tym trzy pergaminowe. Tylko jeden nowożytny dokument sygnowany był podpisem „szeregowej” zakonnicy - Teresy Anny Złotnickiej ${ }^{14}$, choć zapewne wiedzę o jego powstaniu musiała mieć ksieni. Jeden z dokumentów wystawił prokurator franciszkański, ale podpisała się pod nim ksieni, co upoważnia mnie do włączenia go do badanej grupy ${ }^{15}$.

Językiem dominującym dokumentów jest polski. Pojedyncze spisane zostały w języku łacińskim. Jest ich pięć, w tym jeden dyplom średniowieczny, wspominany już pergamin ksieni Staszki. Pozostałe to listy do osób duchownych, ale i świeckich.

W badanej grupie wyróżniono osiem kategorii. Pierwsza to kontrakty, które stanowią największą część wyselekcjonowanego zbioru, blisko połowę - to 77 dokumentów. Kolejne to: ugody -25 , nadania -16 , listy -11 , potwierdzenia -8 , poświadczenia -7 , zezwolenia -7 . W kategorii inne uwzględniono 10 dokumentów o różnorodnej tematyce i charakterze. To dwie prezenty ksień dla plebanów w kościołach, w których klaryski gnieźnieńskie miało prawo patronatu, dwa uwolnienia sołtysa od zaciągów wojskowych oraz zadośćuczynienie wobec dzierżawcy za straty gradowe. Jest także protokół przesłuchania świadków z podpisem ksieni, rezygnacja z szynkowania piwa przez klasztor, przekazanie wójtowi jednej z wsi klarysek, uregulowanie spraw roszczeń finansowych, prośba o wypłacenie kwoty pieniędzy stanowiącej równowartość pretensji konwentu do dóbr strzyżewskich i informacja o wydzierżawieniu przez prokuratora generalnego prowincji dziesięciny kcyńskiej należącej do klarysek tamtejszemu burmistrzowi.

Jak podkreślono na początku, przeważającą część zachowanej spuścizny to dokumenty tyczące różnorodnych spraw gospodarczych: kontrakty dzierżaw gruntów, dziesięcin i budynków gospodarczych (m.in. wiatraków w dobrach zakonnic), nadania gruntów, zezwolenia na budowę w majątku klarysek oraz ugody w sprawach spornych toczonych o dobra ziemskie wspólnoty bądź ustalenie granic majątków klarysek z sąsiadującymi dobrami duchownych i świeckich.

Dokumenty zostały uwierzytelnione przez 31 ksień, począwszy od najstarszych: pergaminu ksieni Staszki z 1371 r. i dokumentu papierowego ksieni Anny Dębickiej/Dębieńskiej (przełożona wspólnoty do 1596 r.), uszkodzonego w miejscu odciśnięcia tłoka pieczętnego i złożenia podpisów ${ }^{16}$. Kolejnymi ksieniami wystawiającymi dokumenty w imieniu zgromadzenia były w XVII wieku: Dorota

${ }^{14}$ AAG, A. Cap. Luzy O 31 k. 45; Borkowska, Leksykon, s. 35.

${ }^{15}$ AAG, A. Cap. Luzy O 28 k. 45 podpisany przez ksienię Katarzynę Teresę Skoroszewską, dlatego włączam do statystyk tej ksieni; Borkowska, Leksykon, s. 32 jako Skoraszewska/Skoroszewska.

${ }^{16}$ AAG, A Cap. Luzy O 46, k. 1; Borkowska, Leksykon, s. 26 ksieni w latach 1596-1609; O.M. Przybyłowicz, Wizytacje klasztoru klarysek w Gnieźnie z lat 1595-1598, w: O rzeczach minionych. Scripta rerum historicarum Annae Rutkowska-Płachcinska oblata, red. M. Młynarska-Kaletynowa, J. Kruppé, Warszawa 2006, s. 259, 262. Na dokumentach nazwiska zakonnic pisane były 
Bromirska (4 razy) $)^{17}$, Katarzyna Lubowicka/Lubowicka (2) ${ }^{18}$, Barbara Golemowska/Golimowska (1) ${ }^{19}$, Katarzyna Obediencja Arkuszewska/Jarkuszewska (3) ${ }^{20}$, Barbara Kunegunda Łaskawska/Laskowska (9) ${ }^{21}$, Katarzyna Eustochia Kłunowska/Klonowska (4) ${ }^{22}$, Zofia Antonina Niedźwiedzka/Miedźwiedzka (5) ${ }^{23}$, Franciszka Wiktoria Cielecka (2) ${ }^{24}$, Anna Obediencja Zabłocka (1 ${ }^{25}$. Następnymi ksieniami znanymi z sygnowania dokumentów w XVIII stuleciu były: Konstancja Klara Doręgowska/Deręgowska (podpisana 3) ${ }^{26}$, Marianna/Marcjanna Salomea Wielowiejska $(1)^{27}$, Katarzyna Teresa Skoroszewska/Skoraszewska $(6)^{28}$, Teresa Lilia Wielowiejska (3) ${ }^{29}$, Helena Krystyna Lubońska (25) ${ }^{30}$, Anna Antonina Prądzyńska (2) ${ }^{31}$, Katarzyna Eufrazja Szygowska (2) ${ }^{32}$, Agata Rozalia Łącka (22) ${ }^{33}$, Katarzyna Jolenta Wierzbińska (7) ${ }^{34}$, Teresa Ludwina Karszewska (9) ${ }^{35}$, Marianna Klara Krasińska (14) ${ }^{36}$, Bogumiła Salomea Silnicka/Sielnicka $(1)^{37}$, Rozalia Konstancja Paruszewska (3) ${ }^{38}$, Teresa Wiktoria Wyganowska $(9)^{39}$, Katarzyna Elżbieta Rzeszotarska (8) ${ }^{40}$, Anna Teresa Baranowska (3) ${ }^{41}$, Ewa Zofia Kraszkowska (2) ${ }^{42}$, Ludwika Franciszka Frezerówna (1) ${ }^{43}$. W XIX wieku podpisy złożyły: Rozalia Serafina Zagajewska (4) ${ }^{44}$ i Róża Aniela Zagajewska (1) ${ }^{45}$.

w różnych wariantach; rzadziej ta sytuacja dotyczy imion. Podobnie jak uczyniła to M. Borkowska w Leksykonie zachowano w niniejszym artykule dwie wersje nazwisk.

${ }^{17}$ Borkowska, Leksykon, s. 27, ksieni w latach 1609-1617; Przybyłowicz, Wizytacje, s. 264.

${ }^{18}$ Borkowska, Leksykon, s. 27, ksieni w latach 1621-1623.

${ }^{19}$ Tamże, ksieni w latach 1627-1629.

${ }^{20}$ Tamże, ksieni w latach 1629-1632, 1635-1646.

${ }^{21}$ Tamże, s. 28, ksieni 1646-1647, 1659-1663.

${ }^{22}$ Tamże, ksieni w latach 1651-1658, 1664-1665, 1668.

${ }^{23}$ Tamże, s. 30, ksieni w latach 1673-1677, 1680-1686, 1695.

${ }^{24}$ Tamże, s. 31, ksieni w latach 1689-1692.

${ }^{25}$ Tamże, ksieni w latach 1692-1701.

${ }^{26}$ Tamże, ksieni w latach 1708-1711.

${ }^{27}$ Tamże, s. 32, ksieni w latach 1704-1708, 1711-1714.

${ }^{28}$ Tamże, ksieni w latach 1714-1720.

${ }^{29}$ Tamże, s. 33, ksieni w latach 1730-1733.

${ }^{30}$ Tamże, ksieni w latach 1720-1726, 1741-1747.

${ }^{31}$ Tamże, ksieni w latach 1747-1750.

${ }^{32}$ Tamże, s. 34, ksieni w latach 1726-1730.

${ }^{33}$ Tamże, ksieni w latach 1733-1736, 1738-1741.

${ }^{34}$ Tamże, ksieni w latach 1736-1738.

${ }^{35}$ Tamże, ksieni w latach 1750-1756.

${ }^{36}$ Tamże, ksieni w latach 1762-1765, 1768-1771.

${ }^{37}$ Tamże, wymieniona bez urzędu ksieni.

${ }^{38}$ Tamże, s. 35, ksieni w latach1765-1768.

${ }^{39}$ Tamże, ksieni w latach 1756-1762.

${ }^{40}$ Tamże, s. 36, ksieni w latach 1771-1777.

${ }^{41}$ Tamże, ksieni w latach 1777-1780.

${ }^{42}$ Tamże, s. 37 ksieni w latach 1786-1795.

${ }^{43}$ Tamże, s. 36, ksieni w latach 1795-1799.

${ }^{44}$ Tamże, s. 37, ksieni w latach 1802-1815, 1825.

${ }^{45}$ Tamże, ksieni od 1825 r.? 
Kwerenda w zespołach AAG A. Cap i A. Cap II umożliwiła uzupełnienie, a niekiedy skorygowanie danych biograficznych zebranych przez M. Borkowską prowadzącą przed laty badania prozopograficzne wielu wspólnot. W przypadku konwentu w Gnieźnie korekty dotyczą zarówno wiadomości o ksieniach, tzn. latach kadencji oraz sprawowaniu przez nich innych urzędów, jak i pozostałych zakonnicach. Informacje zawarte $\mathrm{w}$ analizowanych aktach pozwoliły na ustalenie, iż Silnicka/Sielnicka była ksienią, co nie zostało uwzględnione przez autorkę Leksykonu. Udało się także określić, że inna przełożona Salomea Węgierska posługiwała się imieniem zakonnym Katarzyna ${ }^{46}$. Z podobną sytuacją mamy do czynienia w przypadku szeregowej zakonnicy Agaty Jedleckiej - w Leksykonie występującej bez imienia nadanego w trakcie ceremonii obłóczyn. W świetle dokumentu z 1657 r. posługiwała się ona imieniem zakonnym Angelika ${ }^{47}$.

\section{Kancelaria klasztorna w praktyce}

Prezentowany zbiór umożliwia odtworzenie praktyki kancelaryjno-pisarskiej wspólnoty św. Klary w Gnieźnie w epoce nowożytnej. Temat ten nie był do tej pory poruszany $\mathrm{w}$ literaturze przedmiotu poświęconej klasztorom żeńskim tego okresu ${ }^{48}$. W konwencie klarysek, choć zapewne nie tylko tej żeńskiej wspólnoty, nie można mówić o kancelarii rozumianej jako zorganizowana, profesjonalna instytucja z grupą urzędników pracujących w określonym i stałym miejscu, jak było to w przypadku kancelarii książęcych, królewskich oraz biskupich. Mamy do czynienia z przygotowywaniem, najczęściej przez anonimowe osoby, dokumentów w konkretnej sytuacji i potrzebie klasztoru. Czyniono to rzecz jasna według zasad ówczesnej dyplomatyki, lecz używano, jak wynika z analizy, prostych i podstawowych formuł kancelaryjnych. Ze względu na brak cech charakterystycznych dokumentów klarysek, trudno określić, kto był odpowiedzialny za ich sporządzenie. Tylko w kilku przypadkach można określić osobę spisującą dokument, choć trudno ustalić, czy była ona także odpowiedzialna za jego przygotowanie formalne. Taką możliwość daje porównanie duktu ręki piszącej z duktem podpisów zakonnic pod akcją prawną. Zachowało się kilkanaście akt, które wskazują, iż dokument pisała ksieni lub zakonnica sprawującą urząd sekretarki. Szczególnie ta ostatnia musiała władać piórem dość sprawnie nie tylko w teorii, ale i praktyce, świadczy zresztą o tym charakter jej pisma.

\footnotetext{
${ }^{46}$ O.M. Przybyłowicz, „Hierarchia urzędów i lista ksień klasztoru klarysek w Gnieźnie z XVI -XIX wieku", przygotowywane do druku.

${ }^{47}$ Borkowska, Leksykon, s. 28, zmarła w roku 1673. AAG, A. Cap. Luzy O 37 k. 45.

${ }^{48}$ Zob. J. Gwioździk, Kultura pisma i książi w żeńskich klasztorach dawnej Rzeczpospolitej XVI-XVII w., Katowice 2015, s. 164 stwierdziła lakonicznie, że „w klasztorach nie funkcjonowała kancelaria w znaczeniu używanym w dyplomatyce, potrzebne dokumenty i ich kopie zamawiano, najczęściej opłacając takie usługi na zewnątrz konwentu"; A. Szylar, Liczba zakonnic, skład osobowy i rotacja na urzędach $w$ klasztorze benedyktynek w Sandomierzu w latach 1615-1903, „Nasza Przeszłość", 102 (2004) s. 287-352 wspomniała o siostrach-sekretarkach, podobnie jak. K. Targosz, Piórem zakonnicy. Kronikarki w Polsce XVII w. o swoich zakonach i swoich czasach, Kraków 2002.
} 
Ksienie z XVII stulecia sporządzające akta własną ręką to Kłunowska/Klonowska oraz Łaskawska/Laskowska ${ }^{49}$. W XVIII wieku takich przypadków jest już więcej. Byly to Skoroszewska/Skoraszewska w 1719 r. ${ }^{50}$, Lubońska w 1743 r. ${ }^{51}$, Wyganowska w 1757 r. $^{52}$, Paruszewska w 1765 r. $^{53}$, Krasińska w 1770 r. i 1775 r. ${ }^{54}$, Rzeszotarska w 1774 r. ${ }^{55}$, Kraszkowska w 1787 r. ${ }^{56}$ i Zagajewska w 1809 r. ${ }^{57}$. Dwa dokumenty sporządziła siostra sekretarka Aleksandra Joanna Długołęska (w 1742 i 1747 r.), jeden zaś, już wspominany, został spisany przez Złotnicką (1762 r. $)^{58}$. Ciekawe, że Długołęska na jednym z aktów w 1745 r. podpisała się jako sekretarka i konsyliarka panny ksieni, a nie zgromadzenia ${ }^{59}$.

Przypuszczalnie pozostałe dokumenty wyszły spod ręki pisarzy publicznych lub zakonnych, być może prokuratorów klasztoru Ubogich Panien lub franciszkanów z konwentu gnieźnieńskiego, którzy także bywali - jak wspomniano wyżej osobami uwierzytelniającymi dokumenty sióstr.

Od przełomu XVI i XVII wieku na aktach dotyczących spraw wspólnoty, przygotowywanych oraz wystawianych zapewne w klasztorze, podpis składała przede wszystkim ksieni, niekiedy czyniła to razem z wikarią, rzadko pojawiały się w tej roli inne zakonnice. Stopniowo dopuszczano do sygnowania dokumentów szersze grono, w skład którego wchodziły siostry zwane konsyliarkami. Miały one służyć ksieni radą i decydowały wraz z nią gremialnie o wielu, jeśli nie wszystkich, sprawach klasztoru. Proces poszerzania listy osób podpisujących akta wspólnoty zauważalny jest od początku XVIII wieku. Wówczas oprócz konsyliarek jako osoby uwierzytelniające akta pojawiają się inne urzędniczki - wikaria oraz od lat czterdziestych tego stulecia także sekretarka konwentu. Liczba zakonnic składających podpisy, oprócz ksieni, wahała się między jedną (XVII wieku), najczęściej wikarią, a piętnastoma - w większości konsyliarkami (XVIII wieku).

Klaryski podpisywały się na badanych dokumentach nowożytnych imieniem i nazwiskiem, do którego dodawały pełniony urząd, w formie nazwy pełnej lub skróconej, nawet do jednej litery, np. X - ksieni, K - konsyliarka. Rozmaitość zachowanych form i wariantów pisowni nazwisk i imion oraz dukt podpisów świadczą generalnie, z wyjątkiem kilku zakonnic, o rękach pisarskich niewyrobionych, niewprawnych, trzymających pióro w dłoni raczej okazyjnie. Sytuacja zmieniała się w ciągu stuleci i niektóre podpisy na XVIII-wiecznych dokumentach wskazują już na duży stopień wprawności w piśmie. Do lat czterdziestych XVII wieku siostry podpisywały się wyłącznie imionami świeckimi, co świadczy

\footnotetext{
${ }^{49}$ AAG, A. Cap. Luzy O 32, k. 4 z 1652 r., O 17, k. 19 z 1661 r. i O 29, k. 3 z 1659 r.

${ }^{50}$ AAG, A. Cap. Luzy O 28, k. 44.

${ }^{51}$ AAG, A. Cap. Luzy O 33, k. 43.

${ }^{52}$ AAG, A. Cap. Luzy O 15, k. 17, O 33, k. 70.

${ }^{53}$ AAG, A. Cap. Luzy O 32, k. 58.

${ }^{54}$ AAG, A. Cap. Luzy O 15, k. 23, O 22, k. 48.

${ }^{55}$ AAG, A. Cap. Luzy O 18, k.25.

${ }^{56}$ AAG, A. Cap. Luzy O 27, k. 5.

${ }^{57}$ AAG, A. Cap. Luzy O 19, k. 10-13.

${ }^{58}$ AAG, A. Cap. Luzy O 42, k. 9, O 44, k. 23; O 31, k. 45.

${ }^{59}$ AAG, A. Cap Luzy O 24, k. 13; Borkowska, Leksykon, s. 35.
} 
o dość powolnym procesie adaptacji do prawa potrydenckiego, nakazującego używanie imion zakonnych nadawanych podczas ceremonii wstępowania do klasztoru (obłóczyn). Dopiero od połowy tego stulecia na aktach widnieją obok nazwisk klarysek imiona zakonne, nie zaś świeckie. Pierwsze nowicjuszki, które w Gnieźnie otrzymały imiona zakonne, zostały odnotowane w źródłach klasztornych w 1607 r., choć zwyczaj zmiany imienia przewidywano już w instrukcji obłóczyn, która została spisana około 1600 r. i zachowała się do dziś w AAG. ${ }^{60}$. Instruowano w niej bowiem, pod koniec przebiegu ceremonii: Hic datur novum nomen novitiae genuflexae a Superiore, post haec erectae datur pax ab Abbatissa et Sororibus ${ }^{61}$.

Pierwszą przełożoną, która użyła w dokumencie jednego i drugiego imienia, była Katarzyna Obediencja Arkuszewska. Uczyniła to na trzech dokumentach, wszystkich, które zachowały się z okresu jej rządów. Jej następczyni na urzędzie Barbara Łaskawska/Laskowska na żadnym z aktów nie użyła imienia zakonnego Kunegunda, podobnie jak Katarzyna Kłunowska/Klonowska w zakonie Eustochia. Przebywająca jednak w konwencie w tym samym czasie siostra Nowowiejska na dokumencie prezenty wobec proboszcza kościoła w Kostrzynie, w którym klaryski miały prawo patronatu, podpisała się dwoma imionami: Elżbieta Emilia ${ }^{62}$. Natomiast kolejna po Kłunowskiej/Klonowskiej ksieni, wspominana już Niedźwiedzka/Miedźwiedzka, sygnując dokumenty od końca lat sześćdziesiątych XVII stulecia przedstawiała się już wyłącznie imieniem zakonnym - Antonina. Po niej w ten sposób postępowały kolejne ksienie oraz inne zakonnice przebywające we wspólnocie i podpisujące akta od końca XVII wieku i w kolejnych stuleciach. Można zatem przyjąć, że połowa XVII wieku to czas zastępowania imion świeckich zakonnymi na dokumentach. Jedyną ksienią, która w kolejnym stuleciu używała niekiedy obydwu imion, sygnując akta wspólnoty, była Skoroszewska/Skoraszew$\mathrm{ska}^{63}$. Incydentalnie pojedyncze siostry jeszcze w XVIII wieku posługiwały się imionami świeckimi - w 1705 r., gdy podpis pod aktem wystawionym w imieniu wspólnoty złożyły Katarzyna Solińska w zakonie Magdalena i Jadwiga Osiecka w zakonie Agnieszka ${ }^{64}$.

Zachowane archiwalia klasztoru w Gnieźnie, a także źródła rękopiśmienne innych wspólnot żeńskich pozwalają na konstatację, że co najmniej od drugiej połowy XVI wieku zakonnice posługiwały się piórem na tyle, by móc się podpisać, inne zaś - choć zapewne była to mniejszość - władały nim bieglej ${ }^{65}$. W XVI-

\footnotetext{
${ }^{60}$ Borkowska, Leksykon, s. 27: Katarzyna (Lilia) Górecka, Zofia (Klara) Grochowicka.

${ }^{61}$ O.M. Przybyłowicz, „Pamięć obłóczyn kożdy probantki”. Ceremonia obłóczyn w świetle rękopisu Modus suscipiendi novitias ad habitum S. Clarae z 1600 r. z klasztoru klarysek gnieźnieńskich, HM, 3 (2013) s. 179-194.

${ }^{62}$ AAG, A. Cap. Luzy O 37, k. 45.

${ }^{63}$ AAG, A. Cap. Luzy O 28, k. 44 i 45.

${ }^{64}$ AAG, A. Cap. Luzy O 50, k. 117.

${ }^{65}$ W stołecznym w Krakowie jedynie $20 \%$ kobiet w XVI wieku potrafiło się podpisać, pod koniec wieku zaś w województwie krakowskim ok. 90\% magnatek i 50\% szlachcianek umiało czytać i pisać, W. Urban, Stan oświecenia duchowieństwa krakowskiego w wiekach XVI-XVIII, „Przegląd Historyczny", 74 (1983) z. 3, s. 509-515.
} 
wiecznych księgach grodzkich krakowskich odnotowano kilka przypadków podpisów zakonnic ${ }^{66}$. Na początku XVI stulecia jedna z wrocławskich klarysek - Anna Fribelin ułożyła i spisała modlitwę, w której zawarła rozważania na temat istoty i natury człowieka oraz męki Jezusa Chrystusa ${ }^{67}$. W klasztorze norbertanek w Strzelnie biskup Stanisław Karnkowski, wizytator wspólnoty, zabronił siostrom prowadzenia korespondencji poza wiadomością ksieni, co świadczy o dość wprawnym posługiwaniu się piórem przez część zakonnic ${ }^{68}$. Z końca XVI wieku pochodzi także rękopis norbertanek w Żukowie z wpisami uczynionymi ręką jednej z sióstr ${ }^{69}$. O umiejętności pisania przez mniszki świadczą także marginalia zachowanych rękopisów klasztornych: „Kto ją [książkę - O. M. P] weźmie a nie wróci, ten się wywróci. Kto tę książkę włoży pod futro temu odpadnie ręka jutro" ${ }^{\prime}$. Na verso karty ochronnej „Żywotu Pana Jezusów"71 należącego do klarysek krakowskich zachowały się, począwszy od drugiej dekady XVII stulecia, wpisy wskazujące, że druk przechodził w ręce kolejnych sióstr ${ }^{72}$. W klasztorze klarysek w Starym Sączu zakonnice składały podpisy na dokumentach wspólnoty co najmniej od lat trzydziestych XVII wieku ${ }^{73}$. Zwiększająca się liczba podpisów, m.in. klarysek gnieźnieńskich, starosądeckich i krakowskich świadczy o stopniowym wzroście alfabetyzacji i podnoszeniu się poziomu wykształcenia zakonnic.

${ }^{66} \mathrm{~W}$ dokumencie z 1590 r. sześć klarysek zamiast nazwisk napisało jedynie „ręką swą”, tamże, s. 512.

${ }^{67}$ T. Pietsch, Zur Geschichte des Breslauer Klarenstiftes im Mittelälter, Breslau 1937, s. 25; BUWroc., rkp. I 031, f. $50 \mathrm{r}$ i v.

${ }^{68}$ M. Borkowska, Reforma potrydencka w klasztorze w Strzelnie, „Nasza Przeszłość” (dalej NP), 100 (2004) s. 212.

${ }^{69}$ M. Borkowska, Nieznana autorka norbertańska z końca XVI wieku, NP, 99 (2003) s. 167.

${ }^{70} \mathrm{~K}$. Głombiowski, H. Szwejkowska, Książka rękopiśmienna i biblioteka w starożytności i średniowieczu, Warszawa 1968, s. 222.

${ }^{71}$ Tłumaczonego z hiszpańskiego przez Jana Wachuliusza Lepolitę, wydanego w Krakowie w $1592 \mathrm{r}$.

${ }^{72}$ „Anna Secignowska Sługa Boża Niegodna, Anna Secignowska probantka Świeti Klary, Marina Niewiaroska proszę nie zapominaj mie w niegodnych modlitwach swoich. [...]. Barbara Liposwka [!] Z S M K. Salomea Hebdowna Z S M K”, Katalog poloników XVI wieku Biblioteki Jagiellońskiej, t. 1, red. M. Malicki, E. Zwinogrodzka, Kraków 1992, nr 954. Secignowska to profeska od 1618 r.; Niewiarowska przyjęła habit w 1621 r. Pozostałe dwa wpisy dotyczą sióstr żyjących na przełomie XVII i XVIII wieku: Barbary Lipowskiej (1668-1725) i w XVIII stuleciu: Salomei Hebdówny, P. Gąsiorowska, Skład osobowy klasztoru Klarysek w Krakowie do końca XVIII wieku, Kraków 2005, s. 63, 64, 79, 93, tam brak informacji o notatkach uczynionych przez te siostry.

${ }^{73}$ Np. AGAD, Zbiór A. Czołowskiego rkps. nr 263, k. 212-244 Za tę informację i wgląd w owe dokumenty dziękuję siostrze Salomei Stompel, wikarii i archiwistce w Starym Sączu. Dokumenty z podpisami zakonnic starosądeckich znajdują się również w Centralnym Historycznym Archiwum Ukrainy we Lwowie, O.M. Przybyłowicz, Archiwalia proweniencji zakonnej diecezji krakowskiej w Centralnym Państwowym Archiwum Historycznym Ukrainy we Lwowie, „Studia Źródłoznawcze, 49 (2011) s. 117-125; P. Wiszewski, Opactwo benedyktynek w Legnicy (1348/1349-1810). Struktura, funkcjonowanie, miejsce w społeczeństwie, Poznań-Wrocław 2003, s. 259, przyp. 1617 podał, że źródła z klasztoru benedyktynek w Legnicy po raz pierwszy poświadczają własnoręczne podpisy mniszek w drugiej dekadzie XVII wieku. Informacja dotyczyła ksieni, przeoryszy i podprzeoryszy, a nie szeregowych zakonnic. 
Proces ten można łączyć nie tylko ze zmianami zachodzącymi w społeczeństwie doby staropolskiej, ale i rozkwitem kronikarstwa zakonnego przypadającego na koniec XVII stulecia, a przede wszystkim na kolejny wiek ${ }^{74}$. Siostra Kraszkowska sprawująca urząd sekretarki zgromadzenia gnieźnieńskiego, późniejsza ksieni, dokonała wpisu w „Księdze wszystkich spraw konwentu gnieźnieńskiego” założonej w 1609 r.:

Regestr tego wszystkiego, co się zamyka w tej księdze dziejów Konwentu Gnieźnienskiego WW Panien Franciszkanek z wyrażeniem karty i liczby pod którą czego szukać trzeba, za staraniem P.P. Zofii Kraszkowskiej sekretarki w roku 1776 napisany ${ }^{75}$.

Ta właśnie zakonnica, już jako ksieni, podpisała się na ugodzie zdrobniałą formą imienia - Zosia ${ }^{76}$. To jedyny taki przypadek w historii gnieźnieńskiej wspólnoty.

Innym przejawem indywidualizowania praktyki składania podpisów na dokumentach konwentu w XVIII wieku jest zapis, który pojawił się na akcie nadającym domostwo niejakiemu Walentemu Gabryskowi we wsi klasztornej Krzyszczewie: Klara Krasińska ksieni sygnowała zgodę jako: KK X K G (Klara Krasińska Xieni Konwentu Gnieźnieńskiego ${ }^{77}$. Inne przełożone wspólnoty, których stopień wprawności ręki był zróżnicowany, oprócz nazwiska dodawały pełniony urząd, w formie zapisu: xeni lub xieni oraz używały skrótów: K [Konwentu] G [Gnieźnieńskiego/ Gnieźnińskiego], a nawet samych inicjałów, jak np. X K G Z S M K [Ksieni Konwentu Gnieźnieńskiego Zakonnica Świętej Matki Klary] - co uczyniła np. Szygowska w 1724 r. oraz wzmiankowana Krasińska w roku $1776^{78}$.

Zdarzały się w stuleciu XVIII kontrakty lub ugody, na których w formule testacyjnej widniał jedynie podpis ksieni, choć decyzja na pewno konsultowana była ze wspólnotą, nie zaś podejmowana indywidualnie, bez zasięgnięcia opinii innych sióstr. Zachowały się też kontrakty bądź nadania, na których, przy odbiorze czynszu bądź innych wieloletnich zobowiązań finansowych podpisywało się kilka ksień - te, które zawierały pierwszą umowę, a następnie siostry sprawujące urząd. Tak było np. w 1726 r. w kontrakcie zawartym przez Lubońską z owcza-

${ }^{74}$ Drukiem wydano do tej pory m.in. kroniki karmelitanek bosych, norbertanek w Imbramowicach oraz siedmiu wspólnot benedyktynek kongregacji chełmińskiej: chełmińskich, toruńskich, grudziądzkich, poznańskich, sandomierskich, radomskich i lwowskich, zob. przegląd tej tematyki w: Kronika bernardynek lubelskich 1618-1885, oprac. i wyd. A. Szylar, Lublin 2009, s. 15-16; Klasztory karmelitanek bosych w Polsce, na Litwie i Rusi, t. 1-4, wyd. J. Kalinowski, Kraków 19001904. O kronikarstwie zob. M. Borkowska, Eatanie pamięci, czyli rzecz o klasztornym kronikarstwie retrospektywnym, „Znak”, (1985) nr 480, s. 103-110 oraz K. Targosz, Piórem zakonnicy. Stronę językową kronik norbertańskich analizował natomiast M. Mączyński, Językowy obraz XVII-wiecznego klasztoru sióstr norbertanek w Krakowie na Zwierzyńcu, Kraków 2005.

${ }^{75}$ Strony 796-800 pisane ręką Kraszkowskiej, s. 801-802 inną ręką. O.M. Przybyłowicz, Rękopis Księgi wszystkich spraw Konwentu Gnieźnieńskiego zakonu S. Klary [...] pilnie pisane w roku pańskim 1609 i jego zawartość, HM, 7 (2016) s. 247-263.

${ }^{76}$ AAG, A. Cap. Luzy O 28, k. 79.

${ }^{77}$ AAG, A. Cap. Luzy O 42, k. 17. Wieś w pobliżu Gniezna, w źródłach z epoki występuje także jako Krzeszczewo, Krysczewo, a nawet Chrzeszczewo.

${ }^{78}$ AAG, A. Cap. Luzy O 45, k. 16. 
rzem Maciejem. O odbieraniu kolejnych należności dla klasztoru informowały podpisami Szygowska i Łącka ${ }^{79}$. Podobnie było przy okazji wystawienia aktu przez Karszewską dla Wojciecha Pietrzaka w Winiarach - siedem razy w latach 1752-1761 uwierzytelniała umowę jej następczyni Wyganowska ${ }^{80}$.

W XVII stuleciu ksienie stosowały formułę informującą o zgodzie całej wspólnoty na dany akt prawny. Znacznie rzadziej czyniły to w następnym wieku. Podpisy składało wówczas większe grono urzędniczek. W XVII wieku z formuły podkreślającej zgodę wspólnoty skorzystały: Kłunowska/Klonowska w 1652 r.: „Katarzyna Klonowska ksieni konwentu gniezninskiego i ze wszystkim konwentem”, Łaskawska/Laskowska w 1659 r.: „W panu Bogu życzliwa Barbara Łaskawska X konwentu gnezninskiego i ze wszystkim konwentem panien” oraz Niedźwiedzka/Miedźwiedzka w 1669 r.: „Antonina Miedźwiedzka ksieni konwetu gnizinskiego [!] z wszystkiem konwentem mojem". W XVIII stuleciu zapis zastosowano tylko dwa razy. Użyła formuły Łącka w 1735 r.: „ksieni K G ze świętem zgromadzeniem” i Lubońska w 1745 r.: „X K G swym i konwentu mego imieniem" $"$.

Zachowane akta ukazują realia klasztornego życia, hierarchię struktur wewnętrznych w konwencie i praktykę spisywania aktów. Świadczą o prestiżu i roli, jaką odgrywały we wspólnocie byłe ksienie. Na kontrakcie sygnowanym przez Lubowicką/Łubowicką w 1622 r., zezwalającym na jednoroczną dzierżawę folwarku w Kostrzynie, drugą podpisaną w kolejności była dawna ksieni Dębicka, a dopiero jako trzecia pojawiła się wikaria Katarzyna Zalewska, a zatem teoretycznie druga pod względem ważności po aktualnej przełożonej urzędniczka zakonna $^{82}$. To właśnie wikaria pomagała przecież w zarządzaniu wspólnotą i zastępowała ksienię w większości spraw, gdy ta nie mogła pełnić swoich obowiązków czasowo lub trwale. Być może wymienienie Dębickiej jako drugiej było oznaką szacunku wobec niej, a być może oddawało faktyczną rolę, jaką pełniła w konwencie, choć urzędu już nie sprawowała. Natomiast na dyplomie pergaminowym Arkuszewskiej/Jarkuszewskiej z 1637 r., nadającym sołectwo we wsi klasztornej Woźnikach po ksieni podpisały się „Katarzyna Lubowicka stara X, Barbara Golemowska stara X"83. W drugiej połowie XVII i XVIII wieku praktyką było składanie podpisów z zachowaniem hierarchii urzędów, ustalonej zresztą już w regule św. Klary z 1253 r. - za ksienią powinna podpisywać się wikaria, a potem inne urzędniczki, następnie zaś konsyliarki ${ }^{84}$.

Niektóre dokumenty wystawiane przez konwent, tyczące przede wszystkim spraw gospodarczych - kontrakty i ugody podpisywała także druga strona - osoby świeckie. Niekiedy dopraszały one także swoich przyjaciół jako sygnatariuszy

${ }^{79}$ AAG, A. Cap. Luzy O 45, k. 16 (1726 r.).

${ }^{80}$ AAG, A. Cap. Luzy O 50, k. 74 (1752 r.).

${ }^{81}$ AAG, A. Cap. Luzy O 32, k. 4; O 29, k. 3; O 52, k. 10a; O 33, k. 47; O 24, k. 13.

${ }^{82}$ AAG, A. Cap. Luzy O 37, k. 12.

${ }^{83}$ AAG, Dypl. Gn. nr 886.

${ }^{84}$ Mogła ona, tak jak ksieni, wydawać zgodę np. na rozmowę sióstr przy kracie i rozdzielać zakonnicom różnorodne prace, Reguła, w: Pisma Święci Franciszek i Klara z Asyżu wydanie tacińsko-polskie, Kraków-Warszawa 2002, rozdz. V, s. 470, rozdz. VII, s. 474. 
i poręczycieli, co znajduje odzwierciedlenie w prezentowanym zestawieniu akt. Dotyczyło to przede wszystkim dzierżaw i nadań, akcji prawnych regulujących głównie stosunki gospodarcze i majątkowe między klasztorem a świeckimi.

Nie wiadomo, jaka część z zachowanych dokumentów o charakterze zobowiązań finansowo-gospodarczych wspólnoty, w tym te dotyczące poddanych i dóbr zakonnic, była przedstawiana do zatwierdzenia zwierzchnikom zakonnym podczas wizytacji bądź też braciom z klasztoru św. Franciszka w Gnieźnie, którzy sprawowali formalną (prokurator, spowiednik) lub nieformalną (doradca, gwardian męskiej wspólnoty) pieczę i opiekę nad zakonnicami. Wizytatorzy odwiedzali klasztor raz na trzy lata, jak wynika $z$ akt prowincji oraz wpisów w księgach rachunkowych klarysek. Można więc przypuszczać, że siostry częściej korzystały z rad miejscowych zakonników, prosząc ich o formalną akceptację swoich decyzji i poczynań. Prawdopodobnie aprobata czynności prawnych podejmowanych przez siostry dokonywała się także ustnie, gdyż na pisemną praktykę poświadczania woli zakonnic wskazuje zaledwie kilka przykładów z trzech stuleci. Na przykład w 1611 r. pod wilkierzem dla cechu rzeźnickiego w miasteczku klarysek Kostrzynie oprócz ksieni Bromirskiej, wikarii Lubowickiej/Łubowickiej i siostry Zaleskiej podpisał się także kustosz franciszkanów gnieźnieńskich:

Za consensem JMci Panny Ksini i wszystkich siostr Zakonu Klary Ś w Gnieznie wilkierz przyrzeczony roku 1612 umacnia się przez Br Augustina Kochanskiego kustosza na ten czas gnieznien[skiego] $\mathrm{pm}^{85}$.

Podobna akceptacja znalazła się na ugodzie ksieni Kłunowskiej/Klonowskiej i konwentu z Janem oraz Tomaszem Trzebińskimi w sprawie granic między wsiami Skiereszewo (prywatna własność) i klasztornymi Żernikami. Sygnował umowe franciszkanin Ludwik Cichocki doktor Pisma Świętego, kustosz i gwardian gnieźnieński oraz osoby świeckie, zainteresowane ustaleniem przebiegu granic ${ }^{86}$.

Inny dokument z 1763 r. pozwala stwierdzić, że nie zawsze franciszkanie wydawali zgodę na decyzję podjętą przez siostry. Na verso umowy kontraktowej, sygnowanej wcześniej przez ksienię Krasińską znalazł się taki oto wpis:

Tego kontraktu nie aprobujemy jako z krzywdą WW. Panien Gnieznienskich uczynionego. Działo się w Gnieznie podczas wizyty. X Michał Stalkiewicz prowincjał, X Karol Bonawentura Gorczynski sekretarz i asystent prowincyi.

Nie wiadomo, czy w tym przypadku rzeczywiście nie doszło do realizacji umowy, bo nie sposób ustalić, jaki czas upłynął od sporządzenia aktu do wydania odmownej decyzji przez zwierzchnika.

Ciekawy jest wspominany już dokument wystawiony w Kcyni w 1720 r., informujący o wydzierżawieniu przez prokuratora generalnego prowincji, gwardiana gnieźnieńskiego Kazimierza Januszewskiego dziesięciny snopowej z ról kcyńskich klarysek burmistrzowi tego miasta. Podpisy złożyli pod aktem Januszewski,

${ }^{85}$ AAG, A. Cap. Luzy O 37 k. 3. Kochańskiego w tej roli wymienia A. Karwacki, Stawniejsi franciszkanie w Polsce. Ich życiorysy i dzieła, Kraków 1922, AFKrak., s. 213.

${ }^{86}$ AAG, A. Cap. Luzy O 52, k. 5a. 
ale również ksieni Skoroszewska/Skoraszewska, która przyłożyła też pieczęć klasztoru ${ }^{87}$.

Warto przedstawić jeszcze jedno zagadnienie, wyłaniające się analizy wyżej omawianej spuścizny dokumentowej klarysek, choć na obecnym etapie badań są to uwagi wstępne, wymagające dalszych, pogłębionych studiów - sygnalizowana wcześniej problematyka sfragistyczna. Na dokumentach papierowych wspólnoty nigdy nie zawieszano pieczęci, w przeciwieństwie do dyplomów pergaminowych. Odciskano natomiast tłok w wosku przez papier (pieczęć opłatkowa) lub - znacznie rzadziej - bezpośrednio w wosku na papierze. Była to zresztą praktyka stosowana powszechnie w kancelariach kościelnych i świeckich epoki nowożytnej ${ }^{88}$. Nie zawsze jednak uwierzytelniano dokument wspólnoty gnieźnieńskiej tym właśnie sposobem (oprócz podpisów). Nie są czytelne zależności między użyciem bądź nie pieczęci, a charakterem oraz ważnością dokumentu. Zdarzały się istotne - z punktu widzenia wagi decyzji - akta, do których nie dołączano pieczęci, jak np. nadanie prawa cechowi rzeźników w Kostrzynie w 1670 r., co uczyniła ksieni Niedźwiedzka/Miedźwiedzka ${ }^{89}$. Z drugiej strony zachowały się proste $\mathrm{w}$ formule i treści dokumenty, na których użyto tej formy potwierdzenia akcji prawnej. To np. prośba ksieni Kraszkowskiej z 1787 r. do kapituły gnieźnieńskiej o zgodę na dalsze pobieranie drewna opałowego $\mathrm{z}$ lasu $\mathrm{w}$ Jeziercach ${ }^{90}$.

Pieczęć wyciskano najczęściej na podkładzie z czerwonego wosku, o czym świadczą ślady po użyciu tego materiału, często jego resztki pozostające na papierze po wykruszeniu. Pieczęć opłatkową przykładano niejednokrotnie na kustodium, czasami niezwykle ozdobnym, o delikatnym, ażurowym wzorze, znamionującym wysoki kunszt osoby, która go wykonała. Być może kustodia wykonywała jedna z zakonnic. Na pewno nie sposób mówić o tym, że była to hurtowa „produkcja” kustodiów, gdyż każde z nich było inne, choć stylistyka wskazywać może, iż wykonała je ta sama osoba. Kustodium przykładano do karty aktu pokrytej w tym miejscu czerwonym woskiem i odciskano tłok, sklejając w ten sposób obydwa fragmenty papieru. Zdarzało się też, że woskiem sklejano kartę zginając jeden z dolnych rogów dokumentu.

Na dokumentach klarysek do 1748 r. widnieje odbicie tłoku o ostroowalnym kształcie, o typowo średniowiecznej proweniencji. Bez dokładnej analizy sfragistycznej całości wizerunku oraz paleograficznej otoku trudno ustalić legendę i czas powstania. Wydaje się, że tłok gnieźnieński mógł powstać na przełomie XIII i XIV wieku, biorąc pod uwagę analogiczne zachowane pieczęci innych żeńskich kowentów w średniowieczu, w tym klarysek w Skale i Krakowie ${ }^{91}$. Od dru-

${ }^{87}$ AAG, A. Cap. Luzy O 28, k. 45.

${ }^{88}$ M. Koczerska, Kancelarie i dokumentacja kościelna, w: Dyplomatyka staropolska, red. T. Jurek, Warszawa 2015, s. 352. J. Roguski, Pieczęcie herbowe ksiąząt Sanguszków od XVI do XVIII w., w: Dawne pieczęcie. Typologia - metody badań - interpretacje, red. Z. Piech, Warszawa 2015, s. 435-476.

${ }^{89}$ AAG, A. Cap. Luzy O 32, k. 15.

${ }^{90}$ AAG, A. Cap. Luzy O 27, k. 5.

${ }^{91}$ Pax et bonum. Skarby klarysek krakowskich. Katalog wystawy, red. A. Włodarek, Kraków 1999, s. 24, 28; Z. Piech, Średniowieczne pieczęcie tynieckie, w: Benedyktyni tynieccy w średniowie- 
giej dekady XVIII stulecia akta klasztoru gnieźnieńskiego uwierzytelniano także nowym tłokiem o kształcie owalnym. Łącznie na 37 spośród 158 dokumentów papierowych zastosowano ten sposób potwierdzenia woli wystawcy. Na jednym z nich nie tylko wyciśnięto pieczęć, ale poinformowano o sposobie uwierzytelnienia w jego treści, podobnie jak czyniono to w średniowieczu w formule koroboracji. Dokument został niestety uszkodzony właśnie w miejscu przyłożenia tłoku i podpisów. Z XIX stulecia zachowała się natomiast pieczęć lakowa, którą przystawiała na listach ksieni Serafina Zagajewska ${ }^{92}$.

W Aneksie zestawiono 158 dokumentów papierowych i trzy pergaminowe klasztoru klarysek w Gnieźnie. Podano formy imion i nazwisk zakonnic w transkrypcji, idąc za wskazówkami edycji źródeł nowożytnych, wzorując się m.in. na prozopograficznym materiale zestawionym przez M. Borkowską. Należy podkreślić, iż wielość wariantów nazwisk była bardzo duża. Siostry myliły się, przestawiając litery lub używając niewłaściwych liter, co jest świadectwem niedostatecznych kompetencji piśmienniczych. Pozostawiono tylko najistotniejsze pomyłki w zapisie nazwiska lub urzędu, zaznaczając je wykrzyknikiem w nawiasie kwadratowym [!]. Umieszczono też przy każdym z aktów uwagi o specyficznych cechach formalnych dokumentu, w tym zachowanym odcisku tłoka pieczętnego lub śladach jego użycia. Podano podanto informacje o materiale pisarskim, języku iliczbie kart danej jednostki.

Pozostawiono natomiast różnorodne skróty odnoszące się do określeń wspólnoty i urzędniczek oraz sióstr, uznając że są to cenne informacje o kulturze piśmienniczej konwentu. Nie rozwijano natomiast często stosowanego skrótu $\mathrm{mp}$ lub pm - manu propria/propria manu oraz br. - brat, fr. - frater. Rozwinięto natomiast w nawiasie kwadratowym pozostałe skróty, odnoszące się do urzędów franciszkanów uwierzytelniających dokumenty Ubogich Pań. Wątpliwości odczytu zaznaczono pytajnikiem $\mathrm{w}$ nawiasie kwadratowym [?]. Nazwy oraz numeracja jednostek, podserii i serii w zespołach podano zgodnie z sygnaturami w AAG. Inwentarz zestawiono $\mathrm{w}$ porządku chronologicznym.

Wykaz skrótów pozostawionych:

$\mathrm{G}$, g, gniez/gniz - gnieźnieńskiego

Gn k, K, k, kon - konwent/konwentu

$\mathrm{K}$, kons, konsyl - konsyliarka

K G, k g - konwent gnieźnieński/konwentu gnieźnieńskiego

kon $\mathrm{g}$ - konwent gnieźnieński/konwentu gnieźnieńskiego

sekr - sekretarka

$\mathrm{S}$ - świętej

S K G - siostra konwentu gnieźnieńskiego

czu. Materiaty z Sesji Naukowej Wawel-Tyniec 13-15 X 1994, red. K. Żurowska, Tyniec 1995, s. 121-140; P. Wiszewski, Średniowieczna ślaska pieczęć klasztorna jako środek przekazu informacji (XIII-1.polowa XVI w.), w: Pieczęć w Polsce średniowiecznej i nowożytnej. Zbiór studiów, red. P. Dymmel, Lublin 1998, s. 11-29; L. Wojciechowski, Pieczęcie zakonu paulinów w Polsce do 1630 roku, w: Pieczęć w Polsce, s. 39-53; M.L. Wójcik, Pieczęcie cystersów jemielnickich do połowy XVI wieku (z zespołu Rep. 85 Archiwum Państwowego we Wrocławiu), w: Pieczęć w Polsce, s. 32-37.

${ }^{92}$ AAG, A. Cap. Luzy O 19, k. 10-13 
S M - Świętej Matki

W, w, wik - wikaria

$\mathrm{X}, \mathrm{x}-\mathrm{ksieni}$

X K G - ksieni konwentu gnieźnieńskiego

$\mathrm{Z}$ - zakonnica

Z S - zakonnica świętej

Z S K - zakonnica Świętej Klary

Z S M K - zakonnica Świętej Matki Klary

\begin{abstract}
ANEKS
Dokumenty klasztoru klarysek w Gnieźnie znajdujące się w zespołach: Akta Luźne Kapituła Metropolitalna Konwent Zakonu Klarysek Gniezno (dalej cyt. KZKG), Akta Luźne Kapituła Metropolitalna II oraz Dyplomy Gniezno (dalej cyt. Dypl. Gn.) w Archiwum Archidiecezjalnym w Gnieźnie.
\end{abstract}

1.

14 IV 1371, Gniezno

Ksieni Staszka poświadcza, iż Arnold, mieszczanin gnieźnieński z siostrami Małgorzatą i Krystyną sprzedał Goczkowi, wójtowi gnieźnieńskiemu, sołectwo we wsi klasztornej Woźnikach.

Pergamin, k. 1, łacina

Uwaga: Ślady po przywieszeniu dwóch pieczęci

Or.: Dypl. Gn. nr 191

2.

bez daty [1604-1606], Gniezno

Anna Dębicka ksieni, Dorota Bromirska wikaria, Jadwiga Poleska i Małgorzata Gulczewska potwierdzają sprzedaż wiatraka w Piekarach młynarzowi Matysowi.

Papier, k. 2, j. polski

Uwaga: Dokument bardzo zniszczony, ubytek w części, w której jest data i odciśnięta pieczęć konwentu (informacja o jej przyłożeniu zawarta w tekście). Datacja na podstawie lat życia i sprawowania urzędów wymienionych zakonnic, M. Borkowska, Leksykon, s. 26-27

Or.: A. Cap. Luzy O 46 KZKG XXXIII Majętność Piekary 1600-1796, k. 1

\title{
3.
}

27 VIII 1609, Gniezno

Ugoda Doroty Bromirskiej ksieni i konwentu z Janem Spławskim w sprawie granic między Miniszewem i Kwasotami.

Papier, k. 2, j. polski

Pieczęć ostroowalna wyciśnięta przez papier, druga sygnetowa Spławskiego 
Podpisy: Dorota Bromirska ksieni klasztoru gnieźnieńskiego Katarzyna Łubowicka wikaria, Jan Spławski ręką trzymaną mp

Or.: A. Cap. Luzy O 43 KZKG XXX Majętność Miniszewo ${ }^{93}$ I: 1527-1724, k. 107

4.

11 IV 1611, bez miejsca [Gniezno?]

Nadanie przez konwent cechowi rzeźnickiemu w Kostrzynie wilkierza.

Papier, k. 2, j. polski

Podpisy: Dorota Bromirska ksieni ręką swą, Katarzyna Lubowicka wikaria, Katarzyna Zaleska

Uwaga: W 1612 r. aprobował dokument kustosz gnieźnieński:

„Za consensem JMci Panny Ksini i wszystkich siostr Zakonu Klary S w Gnieźnie wilkierz przyrzeczony roku 1612 umacnia się przez br. Augustyna Kochanskiego kustosza na ten czas gnieznien[skiego] pm"

Or.: A. Cap. Luzy O 37 KZKG XXIV Kostrzyn i Strumiany ${ }^{94}$ I: 1604-1698, k. 3.

5.

16 VIII 1615, Gniezno

Ugoda Doroty Bromirskiej ksieni ze starszymi gminy żydowskiej w sprawie domów żydowskich zbudowanych na gruncie klasztoru.

Papier, k. 2, j. polski

Uwaga: Na k. 2v: brat Feliks Chojewski kustosz i gwardian gnieznienski ręką własną

Or.: A. Cap. Luzy O 31 KZKG XVIII Stosunki z Żydami gnieźnieńskimi 1534-1786, k. 32.

6.

\section{VII 1617, Gniezno}

Dorota Bromirska ksieni z konwentem nadaje Wojciechowi Płotce młyn w Pisz$\mathrm{czu}^{95} \mathrm{i}$ drugi w Korzeczniku.

Pergamin, k. 1, j. polski

Ślady po przywieszeniu jednej pieczęci

Or.: Dypl. Gn. nr 867

\section{7.}

\section{V 1622, Gniezno}

Kontrakt Katarzyny Lubowickiej/Łubowickiej ksieni i konwentu z Anną Kębłowską na jednoroczną dzierżawę folwarku w Kostrzynie i Stronianach.

Papier, k. 2, j. polski

${ }^{93}$ Wieś klarysek w parafii Łopienna, leżąca ok. $25 \mathrm{~km}$ od Gniezna. Jak wynika z akt AAG, A. Cap. Luzy O 43, k. 42, 43, 45 z połowy XVII wieku - pleban z Łopienna potwierdzał odbiór mesznego. W źródłach także pisana jako Miniszewo, Mieniszewo i najczęściej jako Miniszewo.

${ }^{94} \mathrm{~W}$ źródłach nowożytnych także jako wieś zakonnic z folwarkiem pod Kostrzynem. Słownik historyczno-geograficzny województwa poznańskiego w średniowieczu, cz. 1, z. 3, red. A. Gąsiorowski, Wrocław 1986, s. 304 wymieniona w 1534 w źródłach, granicząca z Czerleninkiem, Siedlcem i Wybiartowem (dwie ostatnie także należące do klarysek).

${ }^{95} \mathrm{~W}$ źródłach także jako Piściec, wieś w okolicy Gniezna zakupiona przez konwent w $1616 \mathrm{r}$. 
Dwie pieczęci ostroowalne w czerwonym wosku wyciśnięte przez papier, sygnetowa pieczęć Kębłowskiego

Podpisy: Katarzyna Lubowicka ksieni, Anna Dębicka, Katarzyna Zalewska wikaria, Dorota Piotrowska portulanka, Lilia Górecka, Angelika Zebrzydowska, Jakub Drachowski imieniem pani Anny M Kembłowski

Or.: A. Cap. Luzy O 37 KZKG XXIV Kostrzyn i Strumiany I: 1604-1698, k. 12.

8.

bez daty dziennej i miejsca 1628, [Gniezno?]

Kontrakt Barbary Golemowskiej ksieni i konwentu z młynarzem z Borowca na naprawę młyna w Piszczu z wyszczególnieniem naurialiów stanowiących formę rozliczenia umowy.

Papier, k. 2, j. polski

Podpis: Barbara Golemowska ksieni gnezinska [!]

Or.: A. Cap. Luzy O 33 KZKG XX Majętności Gołąbki, Piszcz, Łomno, Ochodza 1602-1801, k. 19.

9.

22 VI 1635, Miniszewo

Kontrakt Katarzyny Obediencji Arkuszewskiej/Jarkuszewskiej ksieni i konwentu z sołtysem Miniszewa Maciejem na jednoroczną dzierżawę dóbr tamże.

Papier, k. 2, j. polski

Pieczęć ostroowalna wyciśnięta na ozdobnym kustodium

Podpisy: Katarzyna Obediencja Arkuszewska ksieni klasztoru gnieźnieńskiego siostra S Klary, Katarzyna Lubowicka, Zuzanna Dębicka wikaria, Jan Jedlecki pleb[anus] łop[ienski]? mp

Uwaga: Podpisy pięciu innych osób świeckich pod Jedlickim

Or:: A. Cap. Luzy O 43 KZKG XXX Majętność Miniszewo I: 1527-1724, k. 31.

10.

25 II 1637, Gniezno

Katarzyna Obediencja Arkuszewska/Jarkuszewska ksieni wraz z konwentem nadaje Adamowi Rajowi sołectwo w Woźnikach ${ }^{96}$.

Pergamin, k. 1, j. polski

Ślady po przywieszeniu jednej pieczęci

Podpisy: Katarzyna Obediencja Arkuszeska [!] Katarzyna Lubowicka stara X, Barbara Golemowska stara X, Klara Grochowska, Konstancja Sławęcka, Paciencja Chwaliszewska

Uwaga: dokument zniszczony, zawilgocony, częściowo nieczytelny

Or.: Dypl. Gn. nr 886

11.

bez daty dziennej III 1637, Gniezno

Katarzyna Obediencja Arkuszewska/Jarkuszewska ksieni potwierdza odbiór dziesięciny z ról kcyńskich od Wojciecha Baranowskiego, kasztelana kamieńskiego, starosty kcyńskiego.

${ }^{96}$ Wieś klarysek położona ok. 7 km od Gniezna. Atlas historyczny Polski 2017, s. 248. 
Papier, k. 1, j. polski

Pieczęć ostroowalna w czerwonym wosku wyciśnięta przez papier na ozdobnym kustodium

Podpisy: Katarzyna Obediencja Jarkuszewska ksieni, Katarzyna Lubowicka

Or.: A. Cap. Luzy O 28 KZKG XV Dziesięcina z Kcyni 1418-1799, k. 13

12.

6 VIII 1638, Gniezno

Kontrakt Katarzyny Lubowickiej/Łubowickiej ksieni i konwentu z Wojciechem Popowskim na trzyletnią dzierżawę Miniszewa i Posługówka.

Papier, k. 2, j. polski

Pieczęć ostroowalna wyciśnięta przez papier na ozdobnym kustodium

Podpisy: Katarzyna Lubowiecka ksieni stara X Barbara Golimowska, wikaria Klara Grochowicka, Konstancia Sławęcka, Wojciech Popowski mp

Or.: A. Cap. Luzy O 43 KZKG XXX Majętność Miniszewo I: 1527-1724, k. 36

13.

\section{V 1645, Gniezno}

Kontrakt Barbary Kunegundy Łaskawskiej/Laskowskiej ksieni i konwentu z Kacprem i Agnieszką Janowskimi na jednoroczna dzierżawę dóbr Strzyżewo.

Papier, k. 2. j. polski

Podpisy: Barbara Łaskawska ksieni konwentu gnieźnieńskiego, Katarzyna Jarkuszewska, Katarzyna Kłunowska, Klara Grochowicka wikaria, Kasper Janowski mp

Or.: A. Cap. Luzy O 47 Kapituła Metropolitalna KZKG XXXIV Majętność Strzyżewo ${ }^{97}$ I: 1442-1749, k. 8.

14.

12 VI 1646, Gniezno

Kontrakt Barbary Kunegundy Łaskawskiej/Laskowskiej ksieni i konwentu z Stanisławem Chlebowskim na trzyletnią dzierżawę dziesięciny snopowej z ról konwentu w powiecie kcyńskim.

Papier, k. 2, j. polski

Pieczęć wyciśnięta na papierze

Podpisy: Barbara Łaskawska ksieni konwentu gnieźnieńskiego, Barbara Golemowska, Katarzyna Kłunowska wikaria, Katarzyna Chwalikowska

Uwaga: Część dokumentu - dolny fragment, wycięta

Or.: A. Cap. Luzy O 18 KZKG V Majętności. Generalia 1646-1834, k. 1.

15.

bez daty dziennej i miejsca 1645, [Gniezno?]

Ugoda Barbary Kunegundy Łaskawskiej/Laskowskiej ksieni, Katarzyny Arkuszewskiej/Jarkuszewskiej wikarii, Katarzyny Kłunowskiej/Klonowskiej z Pio-

${ }^{97}$ Wieś klarysek położona ok. 10 km na północny-wschód od Gniezna. Atlas historyczny Polski 2017, s. 248. W źródłach także jako Strzyżewo, Strzyżewo Kościelne. 
trem Tworowskim w sprawie zapłaty 60 złotych polskich z tytułu sukcesji nowicjuszce siostrze Korycińskiej.

Papier, k. 1, j. polski

Podpisy: Barbara Łaskawska ksieni klasztoru g, Katarzyna Jarkuszewska, Katarzyna Kłunowska wikaria, Piotr Tworowski

Or.: A. Cap. Luzy O 17 KZKG IV Kapitały, zapisy wyprawy mniszek, skryptu dłużne 1562-1881, k. 14

\section{6.}

\section{V 1652, Gniezno}

Ugoda Katarzyny Eustochii Kłunowskiej/Klonowskiej ksieni i konwentu z Janem i Tomaszem Trzebińskimi w sprawie granic miedzy wsiami Skiereszewo i Żerniki.

Papier, k. 2, j. polski

Pieczęć ostroowalna wyciśnięta na ozdobnym kustodium na podkładzie z wosku

Podpisy: Katarzyna Kłunowska ksieni konwentu gnieźnieńskiego, Agata Jedlecka wikaria, Klara Grochowicka, Barbara Łaskawska, Fr. Ludwik Cichocki Pisma S[więtego] doktor kustosz i gwardian gnieźnieński Franciszka[ński] mp, Jan Trzebinski, Tomasz Trzebiński

Uwaga: Pod podpisami Trzebinskich także podpisy pięciu innych osób świeckich, nie wszystkie czytelne

Or.: A. Cap. Luzy O 52 KZKG XXXIX Majętność Żerniki 1600-1785, k. 5a

17.

\section{XII 1652, Gniezno}

Katarzyna Eustochia Kłunowska/Klonowska ksieni i konwent zawiera kontrakt z mieszczaninem Jakubem Młynkiem na dożywotnią dzierżawę jatki w Gnieźnie.

Papier, k. 2, j. polski

Pieczęć ostroowalna wyciśnięta na papierze

Podpis: Katarzyna Klonowska ksieni konwentu gnieźnieńskiego i ze wszystkim konwentem

Uwaga: Dokument pisany ręką ksieni

Or.: A. Cap. Luzy O 32 KZKG XIX Grzybowo 1614-1833, k. 4

18.

\section{VIII 1657, Gniezno}

Katarzyna Eustochia Kłunowska/Klonowska ksieni i konwent prezentują bp. poznańskiemu Wojciechowi Tolibowskiemu księdza Jacka Kunińskiego na wakujące probostwo w Kostrzynie.

Papier, k. 2, łacina

Pieczęć ostroowalna wyciśnięta przez papier

Podpisy: Katarzyna Kłunowska ksieni konwentu gnieźnieńskiego, Angelika Jedlecka wikaria, Barbara Golemowska, Klara Grochowicka, Pacjencja Chwalikowska, Anna Bieganowska, Barbara Łaskawska, Salomea Węgierska, Elżbieta Emilia Nowowiejska

Or.: A. Cap. Luzy O 37 KZKG XXIV Kostrzyn i Strumiany I: 1604-1698, k. 45 
19.

10 VII 1658, Miniszewo

Kontrakt Barbary Kunegundy Łaskawskiej/Laskowskiej i konwentu z Maciejem i Dorotą Mikołajewskimi na jednoroczną dzierżawę Miniszewa i pustkowia Posługówko.

Papier, k. 2, j. polski

Podpisy: Barbara Łaskawska ksieni K G, Katarzyna Kłunowska, Barbara Brzezieńska, Maciej Mikołajewski imieniem małżonki i swoim

Or:: A. Cap. Luzy O 43 KZKG XXX Majętnośé Miniszewo I: 1527-1724, k. 46

\section{0.}

\section{VII 1658, Gniezno}

Kontrakt Barbary Kunegundy Łaskawskiej/Laskowskiej ksieni i konwentu z Stanisławem Hofmanem na jednoroczną dzierżawę ról kcyńskich.

Papier, k. 1, j. polski

Pieczęć ostroowalna na papierze przez kustodium na podkładzie z wosku

Podpisy: Barbara Łaskawska ksieni K G, Klara Grochowicka, Paciencja Chwalikowska, Salomea Węgierska, Katarzyna Kunowska, Stanisław Hoffman

Or.: A. Cap. Luzy O 28 KZKG XV Dziesięcina z Kcyni 1418-1799, k. 23

\section{1.}

\section{VI 1659, Miniszewo}

Kontrakt Barbary Kunegundy Łaskawskiej ksieni i konwentu z Urbanem i Bogumiłą Gliszczyńskimi na jednoroczną dzierżawę Miniszewa i pustkowia Posługówko.

Papier, k. 2, j. polski

Pieczęć ostroowalna wyciśnięta przez papier na kustodium prostokątnym o szerokości zbliżonej do szerokości karty

Podpisy: Barbara Łaskawska ksieni K gnisninska [!], Agata Jedlecka wikaria, Klara Grochowicka, Pacjencja Chwalikowska, Salomea Węgierska, Katarzyna Kłunowska, Bogumieła Barbara Gliszczyńska ręką trzymaną, Urban Gliszczyński ręką trzymaną

Or.: A. Cap. Luzy O 43 KZKG XXX Majętność Miniszewo I: 1527-1724, k. 49

22.

\section{IX 1659, Gniezno}

Kontrakt Barbary Kunegundy Łaskawskiej/Laskowskiej ksieni i konwentu z Jakubem rzeźnikiem i Wojciechem Klawczykiem rzeźnikiem na dzierżawę jatek mięsnych w Gnieźnie.

Papier, k. 1, j. polski

Podpisy: W panu Bogu życzliwa Barbara Łaskawska x konwentu gnieźnieńskiego i ze wszystkim konwentem panien, Wojciech Klawczyk ręką swą własną podpisuje się

Uwaga: Dokument pisany ręką ksieni

Or.: A. Cap. Luzy O 29 KZKG XVI Posiadłości ziemskie w Gnieźnie 1543-1772, k. 3 


\section{3.}

\section{IX 1661, Gniezno}

Barbara Kunegunda Łaskawska/Laskowska ksieni zeznała, że dała księdzu Andrzejowi Obrowiczowi wikariuszowi kolegiaty św. Jerzego miednicę srebrną pozłacaną w zastaw za 120 zł, które konwent jest mu winien.

Papier, k. 1, j. polski

Pieczęć wyciśnięta przez papier, sklejona karta w dolnym rogu

Podpis: Barbara Łaskawska ksieni konwentu gniezninskiego ze wszystkim konwentem swym Uwaga: Dokument spisany ręką ksieni

Or.: A. Cap. Luzy O 17 KZKG IV Kapitały, zapisy wyprawy mniszek, skryptu dłużne 1562-1881, k. 19.

\section{4.}

30 VI 1662, Gniezno

Kontrakt Barbary Kunegundy Łaskawskiej/Laskowskiej ksieni z ojcem Andrzejem Janczewskim przeorem karmelitów z Kcyni na jednoroczną dzierżawę ról kcyńskich.

Papier, k. 2, j. polski

Pieczęć ostroowalna wyciśnięta przez papier

Podpisy: Barbara Łaskawska ksieni K G, Katarzyna Kunowska [!], Fr Andreas Janczewski, Prior Conventus Kcynen[sis] Ord[nis] Carm[elitanum], Fr Michael Elias Niewiarowski eiusd[em] Con[ven]tus Carm[elitanum] syndicus

Or.: A. Cap. Luzy O 28 KZKG XV Dziesięcina z Kcyni 1418-1799, k. 24

\section{5.}

3 VIII 1665, bez miejsca [Gniezno]?

Katarzyna Eustochia Kłunowska/Klonowska ksieni w imieniu swoim i konwentu potwierdza odbiór 100 zł czynszu od Gliszczyńskiego.

Papier, k. 1, j. polski

Pieczęć ostroowalna wyciśnięta przez papier na zagięciu karty

Podpis: Katarzyna Kłunowska ksieni k g

Or.: A. Cap. Luzy O 43 KZKG XXX Majętność Miniszewo I: 1527-1724, k. 52

26.

20 VII 1669, Gniezno

Ugoda Zofii Antoniny Niedźwiedzkiej/Miedźwiedzkiej ksieni i konwentu ze Stanisławem Wężykiem w sprawie uregulowania sporu o granice dóbr Skiereszewo i Żerniki ${ }^{98}$.

Papier, k. 1, j. polski

Pieczęć ostroowalna wyciśnięta na kustodium

${ }^{98}$ Niegdyś wieś klarysek położona ok. 2 km od Gniezna (obecnie jego dzielnica), Atlas historyczny Polski, s. 248. 
Podpisy: Antonina Miedźwiecka ksieni konwetu [!] gninińskiego [!] z wszystkiem konwentem mojem, Fr. Bernardinus Pawłowski gwardi[an]us gnesnensis Ord[inis] Fr[atrum] Min[orum] Convent[ualium] mp, Stanisław Wężyk

Or.: A. Cap. Luzy O 52 KZKG XXXIX Majętność Żerniki 1600-1785, k. 10a

\section{7.}

bez daty dziennej 1670, Gniezno

Zofia Antonina Niedźwiedzka/Miedźwiedzka i konwent nadają prawo cechowi rzeźnickiemu w Kostrzynie.

Papier, k. 2, j. polski

Podpis: Antonina Miedźwiecka ksieni konwentu gnisinskiego [!]

Or.: A. Cap. Luzy O 32 KZKG XIX Grzybowo 1614-1833, k. 15

\section{8.}

9 I 1671, Gniezno

Zofia Antonina Niedźwiedzka/Miedźwiedzka ksieni i konwent nadają Marcinowi Rybakowi przywilej na karczmę w Strzyżewie.

Papier, k. 2, j. polski

Pieczęć ostroowalna wyciśnięta przez papier na kustodium

Podpisy: Antonia Miedźwiecka X, Barbara Brzezińska wikaria, Katarzyna Węgierska, Agata Jelecka Or.: A. Cap. Luzy O 47 KZKG XXXIV Majętność Strzyżewo I: 1442-1749, k. 106

29.

25 VI 1672, Miniszewo

Kontrakt Zofii Antoniny Niedźwiedzkiej/Miedźwiedzkiej ksieni i konwentu z Bogdanem Gliszczyńskim na trzyletnią dzierżawę Miniszewa i pustkowia Posługówko.

Papier, k. 2, j. polski

Podpisy: Antonina Miedźwiecka ksieni konwentu gnizińskiego, Agata Jedlecka, Helena Borucka, Fr Bernardinus Pawłowski gwardianus gne[snen]sis ac deffinitor prov[inciali]s Ord[inis[ S[ancti] Fra[ncisci] Mi[norum] Co[nventualium] pm, Bogdan Gliszczyński

Or.: A. Cap. Luzy O 43 KZKG XXX Majętność Miniszewo I: 1527-1724, k. 53

30.

13 IX 1678, Gniezno

Zofia Antonina Niedźwiedzka/Miedźwiedzka ksieni z konwentem zezwalają bractwu kuśnierskiemu w Kostrzynie na pobieranie opłaty jarmarcznej od kuśnierzy.

Papier, k. 1 j. polski

Pieczęć ostroowalna wyciśnięta na papierze

Podpis: Antonina Miedźwiecka ksieni gnizińska

Or. A. Cap. Luzy O 37 KZKG XXIV Kostrzyn i Strumiany I: 1604-1698, k. 60 


\section{1.}

\section{VIII 1690, Gniezno}

Franciszka Wiktoria Cielecka ksieni i konwent prezentują biskupowi poznańskiemu Stanisławowi Witwickiemu księdza Wojciecha Padniewskiego na wakujące probostwo w Kostrzynie.

Papier, k. 2, łacina

Pieczęć ostroowalna wyciśnięta przez papier

Podpisy: Wiktoria Cielecka ksieni K G, Antonina Miedźwiecka

Or.: A. Cap. Luzy O 37 KZKG XXIV Kostrzyn i Strumiany I: 1604-1698, k. 68

\section{2.}

\section{IV 1692, Gniezno}

Franciszka Wiktoria Cielecka ksieni z konwentem zezwala mieszczanom Grzybowa, jurydyki klasztoru, na użytkowanie ról konwentu za roczny czynsz w wysokości $200 \mathrm{zł}$.

Papier, k. 1.j. polski

Podpisy: Wiktoria Cielecka ksieni K G, Antonina Miedźwiecka, Obediencja Zabłocka, Helena Borucka, Konstancja Pawłowska

Or.: A. Cap. Luzy O 32 KZKG XIX Grzybowo 1614-1833, k. 14

33.

12 III 1696, Gniezno

Anna Obediencja Zabłocka ksieni konwentu prosi NN. protektora zakonu franciszkańskiego w Rzymie o interwencję u kardynała lub stolicy apostolskiej w sprawie dóbr klasztoru znajdujących się w ruinie.

Papier, k. 2, łacina

Podpis: S[iostra?] Abbatisa Anna claristarum gnesnens [!]

Or.: A. Cap. Luzy O 27 KZKG XIV Listy 1696-1800, k. 1

\section{4.}

\section{VIII 1705, Gniezno}

Kontrakt Marianny Salomei Wielowiejskiej ksieni i konwentu z młynarzem Wawrzyńcem Jarzębińskim na budowę wiatraka, budynków i domostwa w Winiarach, które po 26 latach przejdą na własność klasztoru.

Papier, k. 2, j. polski

Pieczęć ostroowalna wyciśnięta przez papier na zagięciu karty

Podpisy: Salomea Weloweska [!] Z S K ksieni G, Helena Borucka, Anna Zabłocka, Teresa Katarzyna Skoroszewska wikaria, Katarzyna Solińska, Konstancja Doręgowska, Ludwina Karszewska, Jadwiga Osiecka

Or.: A. Cap. Luzy O 50 KZKG XXXVII Majętność Winiary 1557-1799, k. 44 
35.

bez daty rocznej 1708-1711, Gniezno

Konstancja Klara Doręgowska ksieni wraz z konwentem prosi w liście pewnego wojskowego o ochronę dóbr konwentu.

Papier, k. 1, łacina

Pieczęć wyciśnięta na papierze przez ażurowe kustodium

Podpisy: Klara Doręgowska ksieni konwentu gniezińskiego Teresa Skoroszewska wikaria, Lidwina Karszewska konsyliarka, Barbara Kannska [!], Waleria Grodzicka, Cecylia Olszowska, Wiktoria Bąkowska

Uwaga: Datacja na podstawie pełnienia urzędu Doręgowskiej. Kannska nie występuje w Borkowska, Leksykon, najprawdopodobniej to Barbara Kamińska, s. 32

Or.: A. Cap. Luzy O 26 KZKG XIII Podatki państwowe i kontrybucje wojskowe II 1700-1833, k. 22

36.

bez daty dziennej i miejsca 1709, [Gniezno?]

Konstancja Klara Doręgowska ksieni potwierdza odbiór czynszu z dóbr Grotkowo.

Papier, k. 1, j. polski

Podpis: Klara Doregowska ksieni K G

Or.: A. Cap. Luzy O 34 KZKG XX Majętność Grotkowo 1589-1798, k. 13.

\section{7.}

\section{X 1710, Kostrzyn}

Kontrakt Konstancji Klary Doręgowskiej ksieni i konwentu z księdzem Stanisławem Waryskim plebanem kostrzyńskim na budowę cegielni na gruncie konwentu z przeznaczeniem na odbudowę kościoła kostrzyńskiego.

Papier, k. 2, j. polski

Podpisy: Klara Doręgowska ksieni K G, Obediencja Zabłocka, Teresa Skoroszewska, Stanisław Waryski

Or.: A. Cap. Luzy O 38 KZKG XXV Kostrzyn i Strumiany III: 1709-1744, k. 14

38.

bez daty dziennej 1716, Gniezno

Teresa Katarzyna Skoroszewska/Skoraszewska ksieni z konwentem nadaje Walentemu Kuczkowskiemu i jego żonie grunt z budynkiem przy klasztorze w Gnieźnie.

Papier, k. 2, j. polski

Pieczęć ostroowalna wyciśnięta przez papier na kustodium

Podpisy: Teresa Katarzyna Skoroszewska ksieni konwentu gnieźniskiego [!], Salomeja Wielowiejska, Liali Wielewieska [!] wikaria, Kunegunda Kowalska, Apolinara Belęcka, Aniela Rogalińska, Krystyna Lubońska, Antonina Prądzyńska, Julienta Wierbinszka [!], Eufrazja Szygowska, Cecylia Olszowska, Róża Deregowska, Wiktoria Bądkowska, Rozalia Łącka, Świętosława Górzyńska, Ludwina Karszewska

Or.: A. Cap. Luzy O 29 KZKG XVI Posiadłości ziemskie w Gnieźnie 1543-1772, k. 8

Uwaga: Konstancja Róża Deręgowska furtianka i dyskretka, nie zaś Konstancja Klara Doręgowska/ Deręgowska ksieni, Borkowska, Leksykon, s. 34. 
39.

27 VI 1717, Strzyżewo

Kontrakt Katarzyny Teresy Skoroszewskiej/Skoraszewskiej ksieni i konwentu z Teresa Borkową na jednoroczna dzierżawę dóbr w Strzyżewie.

Papier, k. 1, j. polski

Podpisy: Teresa Skoroszewska ksieni, Lilia Wielwieska [!] wikaria, Kunegunda Kowalska, Apolinara Belęcka, Krystyna Lubońska, Antonina Prądzyńska, Julienta [!] Wierzbińska, Cecylia Olszowska, Róża Deręgowska, Wiktoria Badzkowska [!], Rozalia Łącka, Świętosława Górzyńska, Ludwina Karszewska, Salomieja Waleseska [!]

Uwaga: Waleseska to Wielowiejska

Or.: A. Cap. Luzy O 47 KZKG XXXIV Majętność Strzyżewo I: 1442-1749, k. 58

\section{0.}

\section{VI 1717, Strzyżewo}

Ugoda Katarzyny Teresy Skoroszewskiej/Skoraszewskiej ksieni i konwentu z Małgorzatą Kuczyńską w sprawie zaspokojenia wzajemnych pretensji wynikających z dzierżawy dóbr Strzyżewo.

Papier, k. 1, j. polski

Podpisy: Teresa Katarzyna Skoroszewska ksieni, Kunegunda Kowalska, X Kazimierz Januszewski mp, Małgorzata Kuczyńska, Franciszek Józef Kuczyński

Or.: A. Cap. Luzy O 47 KZKG XXXIV Majętność Strzyżewo I: 1442-1749, k. 59

41.

bez daty dziennej (ubytek karty w tym miejscu) VII 1719, Gniezno

Terasa Katarzyna Skoroszewska/Skoraszewska ksieni prosi księdza prokuratora Kazimierza Lewandowskiego, by upomniał przeora karmelitów w Kcyni w sprawie dziesięciny i by przeprowadził rewizję gruntów dzierżawionych przez miasto.

Papier, k. 1, j. polski

Podpis: Teresa Katarzyna Skoroszewska ksieni konwentu gniezniń S Klary

Uwaga: List pisany ręką Skoroszewskiej, u dołu zniszczony i tam ślady po pieczęci wyciśniętej w papierze

Or.: A. Cap. Luzy O 28 KZKG XV Dziesięcina z Kcyni 1418-1799, k. 44

42.

\section{VI 1720, Gniezno}

Kontrakt Katarzyny Teresy Skoroszewskiej/Skoraszewskiej ksieni i konwentu ze Stanisławem Ćwierdzińskim na jednoroczną dzierżawę dóbr w Strzyżewie.

Papier, k. 2, j. polski

Podpisy: Teresa Katarzyna Skoroszewska ksieni, Kunegunda Kowalska, Krystyna Lubońska wik, Apolinara Belęcka, Aniela Rogalińska, Lilia Wielowiejska, Antonina Prądzyńska, Julera [!] Wierzbińska, Eufrazja Szygowska, Cecylia Olszowska, Róża Doręgowska, Wiktoria Batkoska [!], Rozalia Łącka, Świętosława Górzyńska, Ludwina Karszewska

Or.: A. Cap. Luzy O 47 KZKG XXXIV Majętność Strzyżewo I: 1442-1749, k. 64 
43.

1 VI 1720, Kcynia

Prokurator generalny prowincji, gwardian gnieźnieński Kazimierz Januszewski informuje, że wydzierżawił dziesięcinę snopową z ról kcyńskich klarysek burmistrzowi za zgodą konwentu.

Papier, k. 1, j. polski

Pieczęć ostroowalna wyciśnięta przez papier

Podpis: Teresa Katarzyna Skoroszewska ksieni konwentu gnieźnińskiego zakonu Klary Święty, $\mathrm{X}$ [ksiądz] Kazimierz Januszewski Prokurator Prov[inciali]s Gen[era]lis guardianus nd [?] [...] O[rdinis] S[ancti] Fran[cisci] G[nesnensis] mp

Or.: A. Cap. Luzy O 28 KZKG XV Dziesięcina z Kcyni 1418-1799, k. 45

44.

25 VII 1722, Gniezno

Kontrakt Heleny Krystyny Lubońskiej ksieni i konwentu ze Stanisławem Ćwierdzińskim na jednoroczną dzierżawę dóbr w Strzyżewie.

Papier, k. 2, j. polski

Podpisy: Krystyna Lubońska X K G, Apolinara Belęcka, Aniela Rogalińska, Lilia Wielewieska [!], Julenta Wierzbińska, Eufrazja Szygowska, Cycylia [!] Olszowska, Rozalia Łącka, Świętosława Górzyńska

Or.: A. Cap. Luzy O 47 KZKG XXXIV Majętność Strzyżewo I: 1442-1749, k. 68

45.

\section{VII 1722, Gniezno}

Kontrakt Heleny Krystyny Lubońskiej ksieni i konwentu z Tomaszem Grackim na jednoroczną dzierżawę dóbr Miniszewo.

Papier, k. 2, j. polski

Podpisy: Krystyna Lubońska X K G, Teresa Katarzyna Skoroszewska, Apolinara Belęcka, Aniela Roganisko [!], Lilia Wielewiejska, Julienta [!] Wierzbińska, Eufrazja Szygowska, Cecylia Olszowska, Rozalia Łącka, Świętosława Gorzyńska

Uwaga: Roganisko to Anna Aniela Rogalińska, Borkowska, Leksykon, s. 32

Or.: A. Cap. Luzy O 43 KZKG XXX Majętność Miniszewo I: 1527-1724, k. 95

46.

1 IX 1724, Gniezno

Ugoda Heleny Krystyny Lubońskiej ksieni i konwentu z Maciejem Gądkowskim w sprawie polubownego załatwienia sporów o dzierżawę Miniszewa.

Papier, k. 2, j. polski

Podpisy: Krystyna Lubońska X K G, Maci Gądkowski mp, Stani[sław] Szumowski jako przyjaciel Or.: A. Cap. Luzy O 43 KZKG XXX Majętność Miniszewo I: 1527-1724, k. 105 
47.

16 XI 1724, bez miejsca [Gniezno?]

Kontrakt Heleny Krystyny Lubońskiej ksieni i konwentu z Szymonem Wesołowskim na dzierżawę wiatraka w Winiarach.

Papier, k. 2, j. polski

Podpisy: Krystyna Lubońska X K G

Or.: A. Cap. Luzy O 50 KZKG XXXVII Majętność Winiary 1557-1799, k. 54

48.

19 VI 1725, Gniezno

Kontrakt Heleny Krystyny Lubońskiej ksieni i konwentu z Piotrem Olszowskim na jednoroczną dzierżawę dóbr Miniszewo.

Papier, k. 2, j. polski

Podpisy: Krystyna Lubońska ksieni K G, Antonina Prądzyńska, Cecylia Olszowska, Piotr Olszowski Or.: A. Cap. Luzy O 44 KZKG XXXI Majętność Miniszewo II: 1725-1795, k. 1

\section{9.}

10 VII 1726, Gniezno

Helena Krystyna Lubońska ksieni zleca przekazanie Stefanowi Cieńskiemu kwoty 70 talarów kupcowi korzennemu z Torunia Cyriakowi Nesselmanowi, który dostarczał różne rzeczy na potrzeby konwentu.

Papier, k. 1, j. polski

Pieczęć okrągła wyciśnięta przez papier

Podpis: Krystyna Lubońska X K gnieźnińskiego i z całym konwentem moim

Uwaga: Na verso podpis: Cyriak Nesselman

Or:: A. Cap. Luzy O 33 KZKG XX Majętności Gołąbki, Piszcz, Łomno, Ochodza 1602-1801, k. 43

50.

21 IX 1726, bez miejsca [Gniezno?]

Kontrakt Heleny Krystyny Lubońskiej ksieni i konwentu z owczarzem Maciejem na owczarnię w Oborze ${ }^{99}$.

Papier, k. 1, j. polski

Podpisy: Krystyna Lubońska X K G

Uwaga: Dopiski innych ksień:

„Eufrazja Szygowska ksieni K G Z S M K dnia 1 grudnia 1724.

Rozalia Łącka ksieni K G 1733 dnia 12 czerwca.

Wzięnam ad racjam od owczarza oborskiego tynfów sto dziesięć dnia 27 maja roku 1728 na co się własną ręką podpisuję E S X K G

Wzięnam drugą ratą od owczarza oborskiego tynfów sto dziesięć z owiec za rok 1728 dnia 21 pazdziernika na co się podpisuję własną ręką Lilia Wielowiejska ksini gniezskiego [!] konwentu roku 1732 dnia maja 30 ".

Or.: A. Cap. Luzy O 45 KZKG XXXII Majętność Obora 1292-1804, k. 16 s. 248 .

${ }^{99}$ Wieś klarysek położona ok. 7 km na północny zachód od Gniezna, Atlas historyczny Polski, 


\section{1.}

14 VI 1728, Gniezno

Kontrakt Katarzyny Eufrazji Szygowskiej ksieni i konwentu z Piotrem Olszowskim na jednoroczną dzierżawę dóbr Miniszewo.

Papier, k. 2, j. polski

Podpisy: Eufrazja Szygowska ksieni konwentu gniez, Piotr Olszowski

Or.: A. Cap. Luzy O 44 KZKG XXXI Majętność Miniszewo II: 1725-1795, k. 2

52.

\section{VII 1729, Gniezno}

Kontrakt Teresy Lilii Wielowiejskiej ksieni i konwentu z Tomaszem Łaskawskim na jednoroczną dzierżawę dóbr Woźniki.

Papier, k. 2, j. polski

Podpisy: Lilia Wielowiejska ksieni konwentu gnezniskiego [!], Teresa Katarzyna Skoroszewska konsyliarka, Apolinara Belęcka konsyliarka, Eufrozyna Szygowska wikaria, Krystyna Lubońska konsyliarka, Antonina Prądzienska [!] konsyliarka, Julenta Wierzbińska konsyliarka, Cecylia Olszowska konsyliarka, Róża Deręgowska konsyliarka, Rozalia Łącka konsyliarka, Świętosława Górzyńska konsyliarka

Or.: A. Cap. Luzy O 51 KZKG XXXVIII Majętność Woźniki 1575-1796, k. 83

\section{3.}

28 V 1730, Gniezno

Teresa Lilia Wielowiejska ksieni i konwent zezwalają Ignacemu Kaczerkiewiczowi na budowę domu na gruncie klasztoru.

Papier, k. 2, j. polski

Pieczęć okrągła wyciśnięta przez papier na ażurowym kustodium

Podpisy: Lilia Wielowiejska ksieni konwentu gnieznego [!], Teresa Katarzyna Skoroszewska konsyliarka, Eufrazja Szygowska wikaria, Krystyna Lubońska konsyliarka, Antonina Prądzyńska kons, Julenta Wierzbińska konsyliarka, Cecylia Olszowska konsyliarka, Kunegunda Kowalska, Róża Deręgowska, Rozalia Łącka konsyliarka, Świętosława Górzyńska konsyliarka Or.: A. Cap. Luzy O 29 KZKG XVI Posiadłości ziemskie w Gnieźnie 1543-1772, k. 12

54.

22 VII 1732, Gniezno

Kontrakt Teresy Lilii Wielowiejskiej ksieni i konwentu z Tomaszem Łaskawskim na jednoroczną dzierżawę dóbr Woźniki.

Papier, k. 2, j. polski

Podpisy: Lilia Wieleska [!] ksieni

Or.: A. Cap. Luzy O 51 KZKG XXXVIII Majętność Woźniki 1575-1796, k. 87 
55.

15 VII 1733, Gniezno

Rezygnacja Agaty Rozalii Łąckiej ksieni i konwentu z szynkowania piwa dworskiego w Kostrzynie w zamian za zwiększenie dochodów z młynowego i czopowego.

Papier, k. 1, j. polski

Podpisy: Rozalia Łącka ksieni konwentu gnezneńskiego, Krystyna Lubońska, Julenta Wierzbińska, Lilia Wielowiejska, Antonina Prądzyńska, Świętosława Górzyńska, Ludwina Karszewska, prowincjał Piotr Ofierzynski mp

Or.: A. Cap. Luzy O 38 KZKG XXV Kostrzyn i Strumiany III: 1709-1744, k. 37

\section{6.}

30 XII 1733, Gniezno

Ugoda Agaty Rozalii Łąckiej ksieni z Tomaszem i Konstancją Łaskawskimi w sprawie uregulowania wzajemnych pretensji wynikłych z dóbr dzierżawy Woźniki.

Papier, k. 2, j. polski

Podpisy: Rozalia Łącka X K G swoim i zgromadzenia przyronisiego, [!] imieniem, Tomasz Łaskawski, Kosty Łaskawa [!], Fr Matias Rawski penitencjarz proszony mp, Władysław Rychłowski, Grzegorz Kujawski jako przyjaciel, Michał Rokiewski [?] jako przyjaciel

Or.: A. Cap. Luzy O 51 KZKG XXXVIII Majętność Woźniki 1575-1796, k. 89

\section{7.}

24 VI 1734, Gniezno

Kontrakt Agaty Rozalii Łąckiej ksieni i konwentu z Ewą Polewską na jednoroczną dzierżawę dóbr Woźniki.

Papier, k. 1, j. polski

Podpisy: Rozalia Łącka ksieni K G, Kunegunda Kowalska konsyl, Apolinara Belęcka konsyliarka, Krystyna Lubońska k i w, Antonina Prądzyńska dyskretka, Julenta Wierzbińska dyskretka, Eufrazja Szygowska dyskretka, Świętosława Górzyńska dyskretka, Ludwina Karszewska dyskretka, Klara Krasińska dyskretka, Bogumieła Bogusławska konsyliarka, Ewa Polewska Or.: A. Cap. Luzy O 51 KZKG XXXVIII Majętność Woźniki 1575-1796, k. 91

58.

\section{VII 1735, Kostrzyn}

Kontrakt Agaty Rozalii Łąckiej ksieni i konwentu z Piotrem Olszowskim na jednoroczną dzierżawę dóbr Miniszewo.

Papier, k. 2, j. polski

Podpisy: Rozalia Łącka X K G, Julenta Wierzbińska konsyliarka, Piotr Olszowski

Or:: A. Cap. Luzy O 44 KZKG XXXI Majętność Miniszewo II: 1725-1795, k. 3 


\section{9.}

\section{IX 1735, Gniezno}

Umowa Agaty Rozalii Łąckiej ksieni i konwentu z Pawłem Boguńskim na wyrób klepek i rynek z dębów z lasu klarysek na potrzeby klasztoru.

Papier, k. 2, j. polski

Podpisy: Rozalia Łącka ksieni K G ze świętem zgromadzeniem, Paweł Boguński

Or.: A. Cap. Luzy O 33 KZKG XX Majętności Gołąbki, Piszcz, Łomno, Ochodza 1602-1801, k. 47

60.

26 V 1736, Gniezno

Rozliczenie kontraktu Agaty Rozalii Łąckiej i Katarzyny Jolenty Wierzbińskiej ksień z Pawłem Boguńskim.

Papier, k. 1, j. polski

Podpisy: Rozalia Łącka ksieni konwentu gnieszniejskiego [!], Julenta Wierzbińska X K gniezniskie[go]

Or.: A. Cap. Luzy O 33 KZKG XX Majętności Gołąbki, Piszcz, Łomno, Ochodza 1602-1801, k. 49.

61.

\section{VIII 1736, Gniezno}

Kontrakt Katarzyny Jolenty Wierzbińskiej ksieni i konwentu z Jakubem Chwaliszewskim na jednoroczną dzierżawę dóbr w Strzyżewie.

Papier, k. 2, j. polski

Podpisy: Julenta Wierzbińska ksieni K G, Kunegunda Kowalska konsyliarka, Lilia Wielowieska konsyliarka, Krystyna Lubońska konsyliarka, Rozalia Łącka konsyliarka i wikaria, Antonina Prądzyńska konsyliarka, Eufrazja Szygowska konsyliarka, Świętosława Górzyńska konsyliarka, Ludwina Karszewska konsyliarka, Klara Krasińska konsyliarka, Salomea Bogusławska konsyliarka, Febronia Romanówna konsyliarka

Or.: A. Cap. Luzy O 47 KZKG XXXIV Majętność Strzyżewo I: 1442-1749, k. 76

62.

1 III 1737, Gniezno

Katarzyna Jolenta Wierzbińska ksieni potwierdza odbiór pieniędzy i rozliczenie z Pawłem Boguńskim za wykonanie klepek i rynek.

Papier, k.1, j. polski

Podpis: Julenta Wierzbińska ksieni K G

Or.: A. Cap. Luzy O 33 KZKG XX Majętności Gołąbki, Piszcz, Łomno, Ochodza 1602-1801, k. 50

63.

16 VII 1737, Gniezno

Kontrakt Katarzyny Jolenty Wierzbińskiej ksieni i konwentu z Teresą Kierską na jednoroczną dzierżawę dóbr Strzyżewo Kościelne i pustkowia Gołąbki i Piszcz.

Papier, k. 1, j. polski

Podpisy: Julenta Wierzbińska ksieni K G, Teresa Kierska

Or.: A. Cap. Luzy O 33 KZKG XX Majętności Gołąbki, Piszcz, Łomno, Ochodza 1602-1801, k. 51 
64.

4 XI 1737, Gniezno

Kontrakt Katarzyny Jolenty Wierzbińskiej ksieni i konwentu z Antonim i Jadwigą Bojanowskimi na jednoroczną dzierżawę dóbr Woźniki.

Papier, k. 2, j. polski

Podpisy: Julenta Wierzbińska ksieni K G, Krystyna Lubońska konsyliarka, Salomea Sielnicka, Franciszka Czaplicka, Joanna Długołęska, Anna Złotnicka, Katarzyna Zabłocka, Magdalena Wilczyńska

Or.: A. Cap. Luzy O 51 KZKG XXXVIII Majętność Woźniki 1575-1796, k. 94

65.

28 VIII 1737, Gniezno

Katarzyna Jolenta Wierzbińska ksieni prosi księdza Stanisława Zakrzewskiego, by zechciał okazać cierpliwość w oczekiwaniu na zwrot długu.

Papier, k.1, j. polski

Pieczęć okrągła wyciśnięta przez papier

Uwaga: Dokument zniszczony, zawilgocony, tekst słabo czytelny

Or.: A. Cap. Luzy O 27 KZKG XIV Listy 1696-1800, k. 2

\section{6.}

9 VI 1738, Kostrzyn

Ugoda Katarzyny Jolenty Wierzbińskiej ksieni i konwentu z Antonim i Zofią Kamińską w sprawie pretensji wynikłych z dzierżawy Kostrzyna i Stronian.

Papier, k. 1, j. polski

Podpisy: Julenta Wierzbińska ksieni, Antonina Prądzyńska, Katarzyna Zabłocka, Fr. Bonawentura Szydłakowicz, Antoni Kaminski

Or. A. Cap. Luzy O 38 KZKG XXV Kostrzyn i Strumiany III: 1709-1744, k. 45

\section{7.}

30 VII 1738, Gniezno

Katarzyna Jolenta Wierzbińska ksieni prosi niejakiego Borzęckiego, by wypłacił Teresie Kierskiej sumę 225 zł, czyli wysokość pretensji konwentu do dóbr strzyżewskich.

Papier, k. 1, j. polski

Podpis: Julenta Wierzbińska ksini kon gniez i z dyskretkami

Uwaga: Karta zniszczona (ucięta)

Or.: A. Cap. Luzy O 17 KZKG IV Kapitały, zapisy wyprawy mniszek, skryptu dłużne 1562-1881, k. 43

68.

8 VIII 1738, Gniezno

Kontrakt Katarzyny Jolenty Wierzbińskiej ksieni i konwentu z Antonim i Jadwigą Bojanowskimi na jednoroczną dzierżawę dóbr Woźniki. 
Papier, k. 2, j. polski

Podpisy: Julenta Wierzbińska ksieni K G, Lilia Wielewieska [!] konsyliarka, Krystyna Lubońska kons, Antonina Prądzyńska kons, Świętosława Górzyńska konsyliarka, Lidwina Karszewska konsyliarka, Klara Krasińska konsyliarka, Bogumieła Bogusławska konsyliarka

Or.: A. Cap. Luzy O 51 KZKG XXXVIII Majętność Woźniki 1575-1796, k. 96

69.

17 VII 1739, Gniezno

Ugoda Agaty Rozalii Łąckiej ksieni i konwentu z Antonim Świerczyńskim w sprawie zaspokojenia wzajemnych pretensji wynikających z dzierżawy dóbr Strzyżewo.

Papier, k. 2, j. polski

Podpisy: Rozalia Łącka X K G, Joanna Długołęska sekretarka, Antoni Świerczyński, Jakub Chwaliszewski mp, Antoni Ryszyk jako przyjaciel konwentu gnes[nieńskiego], Stanislaw Wysczycki, Antoni Leski mp jako przyjaciele

Or.: A. Cap. Luzy O 47 KZKG XXXIV Majętność Strzyżewo I: 1442-1749, k. 79

70.

14 IV 1740, Gniezno

Kontrakt ksieni Agaty Rozalii Łąckiej ze Stanisławem Chwaliszewskim na trzyletnią dzierżawę Kostrzyna za 8 tys. zł.

Papier, k. 4, j. polski

Podpis: Rozalia Łącka X K G, Stanisław Chwaliszewski

Or.: A. Cap. Luzy O 38 KZKG XXV Kostrzyn i Strumiany III: 1709-1744, k. 54

71.

6 VIII 1740, Miniszewo

Ugoda Agaty Rozalii Łąckiej ksieni i konwentu z Andrzejem Lisowskim w sprawie zaspokojenia pretensji wynikających z dzierżawy dóbr Miniszewo.

Papier, k. 2, j. polski

Podpis: Rozalia Łącka ksieni konwentu gniezniejskiego [!], Joanna Długołęska Z S Matki Klary, Andrzej Lisowski ręką trzymaną, Maci Zoraski jako przyjaciel, Jakub Karłowski jako przyjaciel Or.: A. Cap. Luzy O 44 KZKG XXXI Majętność Miniszewo II: 1725-1795, k. 15

72.

2 II 1741, Gniezno

Kontrakt Agaty Rozalii Łąckiej ksieni z Pawłem Boguńskim na sprzedaż dębów z lasu w Gołąbkach i wyrób klepek.

Papier, k. 1, j. polski

Podpis: Rozalia Łącka ksien [!] K G

Or.: A. Cap. Luzy O 33 KZKG XX Majętności Gołąbki, Piszcz, Łomno, Ochodza 1602-1801, k. 116 
73.

26 VI 1741, Gniezno

Kontrakt Agaty Rozalii Łąckiej ksieni i konwentu z Andrzejem Zabłockim na trzyletnią dzierżawę dóbr w Strzyżewie, Piszczu i Gołąbkach.

Papier, k. 2, j. polski

Podpis: Rozalia Łącka ksieni konwentu G, Andrzej Zabłocki

Or.: A. Cap. Luzy O 47 KZKG XXXIV Majętność Strzyżewo I: 1442-1749, k. 83

74.

26 VI 1741, Gniezno

Kontrakt Agaty Rozalii Łąckiej ksieni i konwentu z Wojciechem Rębowskim na trzyletnią dzierżawę dóbr Miniszewo.

Papier, k. 2, j. polski

Podpisy: Rozalia Łącka ksieni konwentu gniezniejskiego [!], Wojciech Rębowski

Or.: A. Cap. Luzy O 44 KZKG XXXI Majętność Miniszewo II: 1725-1795, k. 17

75.

4 VII 1741, Miniszewo

Kontrakt Heleny Krystyny Lubońskiej ksieni i konwentu z Wojciechem Rębowskim na trzyletnią dzierżawę dóbr Miniszewo.

Papier k. 2, j. polski

Podpisy: Krystyna Lubońska X K G, Wojciech Rębowski

Or. A. Cap. Luzy O 44 KZKG XXXI Majętność Miniszewo II: 1725-1795, k. 18

\section{6.}

24 VI 1742, Gniezno

Helena Krystyna Lubońska ksieni i konwent uwalniają sołtysa w Krzyszczewie od wszelkiego zaciągu.

Papier, k. 2, j. polski

Pieczęć okrągła odciśnięta na papierze

Podpisy: Krystyna Lubońska ksieni konwentu gnieźnińskiego, Lilia Wielowiejska konsyliarka, Rozalia Łącka konsyliarka, Świętosława Górzyńska konsyl i wikaria, Ludwina Karszewska konsyliarka, Klara Krasińska konsyliarka, Bogumieła Bogusławska konsyliarka, Salomea Sielnicka k, Joanna Długołęska Z S K sekretarka Gniz Kon Uwaga: Dokument pisany ręką Długołęskiej

Or.: A. Cap. Luzy O 42 KZKG XXXIX Majętność Krzyszczewo 1611-1796, k. 9

77.

29 VIII 1743, Kostrzyn

Ugoda Heleny Krystyny Lubońskiej ksieni i konwentu ze Stanisławem Chwaliszewskim w sprawie pretensji wynikłych z dzierżawy Kostrzyna i Stronian.

Papier, k. 2, j. polski 
Podpisy: Krystyna Lubońska ksieni K G, Antonina Prądzyńska, Joanna Długołęska, Franciszek Wolinski archidiakon śremski, Chwaliszewski

Or.: A. Cap. Luzy O 38 KZKG XXV Kostrzyn i Strumiany III: 1709-1744, k. 72

78.

6 IX 1743, Kostrzyn

Kontrakt Heleny Krystyny Lubońskiej ksieni i konwentu z Petronelą i Piotrem Otockim i na trzyletnią dzierżawę dóbr Kostrzyn i Strumiany.

Papier, k. 2 j. polski

Podpisy: Krystyna Lubońska ksieni K G, Piotr Otocki ręką trzymaną

Or.: A. Cap. Luzy O 38 KZKG XXV Kostrzyn i Strumiany III: 1709-1744, k. 75

79.

16 IX 1743, Kostrzyn

Helena Krystyna Lubońska ksieni i konwent zezwala cechowi piwowarskiemu w Kostrzynie na wyrób piwa zgodnie ze zwyczajem.

Papier, k. 1, j. polski

Podpisy: Krystyna Lubońska ksieni K G, Piotr Otocki ręką trzymaną

Or.: A. Cap. Luzy O 38 KZKG XXV Kostrzyn i Strumiany III: 1709-1744, k. 73

80.

21 XI 1743, Gniezno

Poświadczenie Heleny Krystyny Lubońskiej ksieni, w którym stwierdza, że jest winna niejakiemu panu Bogońskiemu 750 zł pożyczonych pod zastaw sreber i obiecuje oddać na Trzech Króli roku 1744.

Papier, k. 1, j. polski

Podpisy: Krystyna Lubońska X K G, Rozalia Łącka konsyliarka

Uwaga: Pisane ręką ksieni

Or.: A. Cap. Luzy O 22 KZKG IX Rachunki, pokwitowania 1573-1834, k. 25

\section{1.}

10 VIII 1744, Kostrzyn

Kontrakt Helena Krystyny Lubońskiej ksieni i konwentu z Jakubem Łojewskim na jednoroczną dzierżawę browarów i gościńców w dobrach Kostrzyn i Strumiany.

Papier, k. 1, j. polski

Podpisy: Krystyna Lubońska ksieni K G, Salomea Bogusławska, Joanna Długołęska sekretarka, Agnieszka Konarzewska, Jakub Łojewski

Or.: A. Cap. Luzy O 38 KZKG XXV Kostrzyn i Strumiany III: 1709-1744, k. 83

82.

20 VI 1744, Kostrzyn

Protokół przesłuchania świadków w sprawie o obrazę ksieni.

Papier, k. 1, j. polski 
Podpis: Krystyna Lubońska X K G

Or.: A. Cap. Luzy O 38 KZKG XXV Kostrzyn i Strumiany III: 1709-1744, k. 84

\section{3.}

\section{IX 1744, Gniezno}

Kontrakt Heleny Krystyny Lubońskiej ksieni i konwentu z Józefem Anstrukiem na trzyletnią dzierżawę dóbr w Strzyżewie.

Papier, k. 1, j. polski

Podpisy: Krystyna Lubońska X K G, Józef Anstruk

Or.: A. Cap. Luzy O 47 KZKG XXXIV Majętność Strzyżewo I: 1442-1749, k. 94

\section{4.}

\section{IX 1744, Gniezno}

Helena Krystyna Lubońska ksieni poświadcza, że konwent winien jest Janowi Białkowskiemu 20 wierteli jęczmienia i obie strony wycofują sprawę z sądu grodzkiego.

Papier, k. 1, j. polski

Podpis: Krystyna Lubońska X K G, Joanna Długołęska Z S K, Stanisław Zaleski jako przytomny przy tej kombinacyi

Uwaga: Dukt pisma dokumentu ręką Stanisława Zaleskiego. 18 IX 1744 Białkowski stwierdził, że jego pretensje zostały zaspokojone i podpisał jeszcze raz

Or:: A. Cap. Luzy O 17 KZKG IV Kapitały, zapisy wyprawy mniszek, skryptu dłużne 1562-1881, k. 47

\section{5.}

\section{V 1745, Gniezno}

Kontrakt Heleny Krystyny Lubońskiej ksieni i konwentu z młynarzem Marcinem Bekierewiczem na trzyletnią dzierżawę młyna w Strzyżewie.

Papier, k. 2, j. polski

Podpisy: Krystyna Lubońska X K G, Joanna Długołęska sekretarka i zakrystianka K G, Lilia Wielowiejska konsyliarka, Antonina Prądzyńska konsyliarka, Rozalia Łącka konsyliarka, Świętosława Górzyńska konsyliarka, Ludwina Karszewska konsyliarka i wikaria, Klara Krasińska konsyliarka, Salomea Bogusławska konsyliarka, Salomea Sielnicka K, Marcin Bekierewicz ręką trzymaną Or.: A. Cap. Luzy O 47 KZKG XXXIV Majętność Strzyżewo I: 1442-1749, k. 96

\section{6.}

\section{V 1745, Kostrzyn}

Ugoda między Heleną Krystyną Lubońską ksienią i konwentem, a Melchiorem Skórzewskim w sprawie poddanych.

Papier, k. 1, j. polski

Podpis: Krystyna Lubońska X K G swym i konwentu mego imieniem, Joanna Długołęska sekretarka i dyskretka P. Ksni [!], Melchior Skorzewski mp

Or.: A. Cap. Luzy O 24 KZKG XI Poddani 1583-1786, k. 13 


\section{7.}

23 IV 1747, Gniezno

Kontrakt Heleny Krystyny Lubońskiej ksieni i konwentu z Kazimierzem Batkowskim na wieczystą dzierżawę wiatraka w Kostrzynie.

Papier, k. 1, j. polski

Pieczęć okrągła wyciśnięta przez papier

Podpisy: Krystyna Lubońska X K gniezin, Antonina Prądzyńska konsyliarka, Rozalia Łącka konsyliarka, Świętosław Górzyńska konsyliarka, Ludwinia Karszewska konsyliarka, Klara Krasińska konsyliarka, Bogumiła Bogusławska konsyliarka, Salomea Sielnicka konsyliarka, Joanna Długołęska sekretarka

Or.: A. Cap. Luzy 39 KZKG XXVI Kostrzyn i Strumiany IV:1745-1766, k. 14

\section{8.}

\section{IV 1747, Gniezno}

Kontrakt Heleny Krystyny Lubońskiej ksieni i konwentu z Piotrem Główczyńskim na dzierżawę dóbr Gołąbki z obowiązkiem wybudowania osady i zwolnieniem z tego powodu z opłaty czynszów na cztery lata.

Papier, k. 1, j. polski

Podpisy: Krystyna Lubońska ksieni, Antonina Prądzyńska, Rozalia Łącka konsyliarka,

Świętosława Górzyńska konsyliarka, Ludwina Karszewska wikaria, Klara Krasińska konsyliarka, Salomea Bogusławska wikaria, Salomea Sielnicka konsyliarka, Joanna Długołęska kons i sekretarka Or.: A. Cap. Luzy O 33 KZKG XX Majętności Gołąbki, Piszcz, Łomno, Ochodza 1602-1801, k. 59

89.

30 IV 1747, Gniezno

Kontrakt Heleny Krystyny Lubońskiej ksieni i konwentu z Melchiorem i Anna Kaliszkowskimi na trzyletnią dzierżawę dóbr w Strzyżewie.

Papier, k. 2, j. polski

Podpisy: Krystyna Lubońska X K G, Melchior Kaliszkowski, Anna Kalyzkoska [!]

Or.: A. Cap. Luzy O 47 KZKG XXXIV Majętność Strzyżewo I: 1442-1749, k. 100.

90.

15 V 1747, Gniezno

Kontrakt Heleny Krystyny Lubońskiej ksieni i konwentu z Stanisławem i Bogumiłą Kozakiewiczami na trzyletnią dzierżawę dóbr Woźniki.

Papier, k. 2, j. polski

Podpisy: Krystyna Lubońska X K G, Stanisław Kozakiewicz, Bogumieła Kozakiewiczowa

Or.: A. Cap. Luzy O 51 KZKG XXXVIII Majętność Woźniki 1575-1796, k. 110

91.

26 VI 1747, Miniszewo

Kontrakt Heleny Krystyny Lubońskiej ksieni i konwentu z Stefanem Białęskim na trzyletnią dzierżawę dóbr Miniszewo. 
Papier, k. 2, j. polski

Podpisy: Krystyna Lubońska X K G, Joanna Długołęska S K G, Stefan Białeski

Or.: A. Cap. Luzy O 44 KZKG XXXI Majętność Miniszewo II: 1725-1795, k. 22

92.

29 VI 1747, Piekary

Helena Krystyna Lubońska ksieni i konsyliarka Aleksandra Joanna Długołęska zobowiązują się do oddania Stefanowi Białęskiemu dzierżawcy dóbr Miniszewo $100 \mathrm{zł}$.

Papier, k. 1, j. polski

Podpisy: Krystyna Lubońska ksieni, Joanna Długołęska

Uwaga: Dokument pisany przez Długołęską

Or.: A. Cap. Luzy O 44 KZKG XXXI Majętność Miniszewo II: 1725-1795, k. 23

93.

23 III 1748, Gniezno

Anna Antonina Prądzyńska ksieni i konwent nadają bractwu piwowarskiemu w Kostrzynie kontrakt na młynek koński (słodowiec).

Papier, k. 5, j. polski

Pieczęć ostroowalna wyciśnięta przez papier na ozdobnym kustodium

Podpisy: Antonina Pradensa ksini [!] K G, Rozalia Łącka konsyliarka, Świętosława Górzyńska konsyliarka i wikaria, Ludwina Karszewska konsyliarka, Bogumiła Bogusławska konsyliarka [i] sekretarka, Salomea Sielnicka konsyliarka, Joanna Długołęska konsyliarka, Anna Teresa Złotnicka konsyliarka, Katarzyna Zabłocka konsyliarka, Magdalena Wilczyńska konsyliarka

Or.: A. Cap. Luzy 39 KZKG XXVI Kostrzyn i Strumiany IV:1745-1766, k. 18

\section{4.}

\section{V 1748, Gniezno}

Kontrakt Anny Antoniny Prądzyńskiej ksieni i konwentu z Piotrem Główczyńskim na trzyletnią dzierżawę Piszcza.

Papier, k. 2, j. polski

Podpisy: Antonina Prądzyńska ksieni, Rozalia Łącka, Świętosława Górzyńska, Ludwina Karszewska, Bogumiła Bogusławska

Or.: A. Cap. Luzy O 33 KZKG XX Majętności Gołąbki, Piszcz, Łomno, Ochodza 1602-1801, k. 60

\section{5.}

\section{VII 1750, Woźniki}

Ugoda Teresy Ludwiny Karszewskiej ksieni i konwentu ze Stanisławem Kozakiewiczem w sprawie zaspokojenia wzajemnych pretensji wynikłych z dóbr dzierżawy Woźniki.

Papier, k. 2, j. polski

Podpisy: Ludwina Karszewska ksieni konwentu gnizinskie [!], Rozalia Łącka konsyliarka, Stanisław Kozakiewicz

Or.: A. Cap. Luzy O 51 KZKG XXXVIII Majętność Woźniki 1575-1796, k. 114. 


\section{6.}

27 VII 1750, Gniezno

Ugoda Teresy Ludwiny Karszewskiej ksieni z Stefanem Białęskim w sprawie zaspokojenia pretensji wynikających z dzierżawy dóbr Miniszewo.

Papier, k. 2, j. polski

Podpisy: Ludwina Karszewska ksieni konwentu gnizińskiego, Rozalia Łącka konsyliarka, Wiktoria Wyganowska Z S M K, Apolinara Belęcka sekretarka, Stefan Białęski, Maci Zorawski jako przyjaciel mp, Wojciech Arcemberski jako przyjaciel mp

Or.: A. Cap. Luzy O 44 KZKG XXXI Majętność Miniszewo II: 1725-1795, k. 27

97.

31 VII 1750, Miniszewo

Kontrakt Teresz Ludwiny Karszewskiej ksieni i konwentu z Wojciechem Arcemberskim na prawo propinacji w dobrach Miniszewo.

Papier, k. 1, j. polski

Podpisy: Ludwina Karszewska X K G, Rozalia Łącka konsyliarka, Wiktoria Wyganowska Z S M K, Apolinara Belęcka sekretarka Z S M K, Wojciech Arcemberski mp

Or.: A. Cap. Luzy O 44 KZKG XXXI Majętność Miniszewo II: 1725-1795, k. 29

98.

6 IX 1750, Gniezno

Kontrakt Teresy Ludwiny Karszewskiej ksieni i konwentu z Jakubem Łojewskim na jednoroczną dzierżawę dóbr Woźniki.

Papier, k. 1, j. polski

Podpisy: Ludwina Karszewska ksieni K G, Jakub Łojewski mp

Or.: A. Cap. Luzy O 51 KZKG XXXVIII Majętność Woźniki 1575-1796, k. 112a

99.

bez daty dziennej XI 1750, Gniezno

Kontrakt Bogumiły Salomei Sielnickiej ksieni i konwentu z Wojciechem Astrakowskim na sześcioletnie pozyskiwanie ról w dobrach klarysek Piszczu.

Papier, k. 1, j. polski

Podpisy: Salomea Sielnicka ksieni, Joanna Długołęska, Anna Złotnicka, Katarzyna Zabłocka, Magdalena Wilczyńska konsyliarki

Or.: A. Cap. Luzy O 33 KZKG XX Majętności Gołąbki, Piszcz, Łomno, Ochodza 1602-1801, k. 62

100.

4 I 1751, Gniezno

Teresa Ludwina Karszewska ksieni i konwent uwalniają Walentego z Krzyszczewa od wszelkich powinności za wyjątkiem czynszu w wysokości 104 zł oraz nadają mu prawo szynkowania piwa i gorzałki.

Papier, k. 1, j. polski

Podpis: Ludwina Karszewska ksieni konwentu G

Or.: A. Cap. Luzy O 42 KZKG XXXIX Majętność Krzyszczewo 1611-1796, k. 14 
101.

16 VI 1751, Gniezno

Kontrakt Teresy Ludwiny Karszewskiej ksieni i konwentu z Antonim Nowickim na nowy gościniec w Winiarach.

Papier, k. 1, j. polski

Podpisy: Ludwina Karszewska ksieni K G

Or.: A. Cap. Luzy O 50 KZKG XXXVII Majętność Winiary 1557-1799, k. 72.

102.

\section{VI 1751, Woźniki}

Kontrakt Teresy Ludwiny Karszewskiej ksieni i konwentu z Wawrzyńcem Łojewskim na dwuletnią dzierżawę dóbr Woźniki.

Papier, k. 1, j. polski

Podpisy: Ludwina Karszewska X K G, Joanna Długołęska kons, Katarzyna Zabłocka konsyliarka, Wawrzyniec Łojewski

Or.: A. Cap. Luzy O 51 KZKG XXXVIII Majętność Woźniki 1575-1796, k. 115

103.

30 VI 1751, Gniezno

Kontrakt Teresy Ludwiny Karszewskiej ksieni i konwentu na trzyletnią dzierżawę dóbr w Strzyżewie.

Papier, k. 2, j. polski

Podpisy: Ludwina Karszewska ksieni konwentu G, Antonina Prądzyńska konsyliarka, Świętosława Górzyńska konsyliarka, Joanna Długołęska konsyl, Katarzyna Zabłocka konsyliarka

Uwaga: Na dole: „Odebrałam od Imci Pana Kaliszkowskiego arendy konwenckie należący za rok 1752 ”

Podpis: Lidwina Karszewska ksieni konwentu G, Świętosława Górzyńska konsyliarka

Or.: A. Cap. Luzy O 48 KZKG XXXV Majętność Strzyżewo II: 1751-1793, k. 2

104.

16 VII 1752, Gniezno

Teresa Ludwina Karszewska ksieni i konwent nadają Szymonowi Pruskiemu przywilej na młyn wodny w Strzyżewie.

Papier, k. 2, j. polski

Podpisy: Ludwina Karszewska ksieni konwentu G, Antonina Prądzyńska konsyliarka, Rozalia Łącka konsyliarka, Świętosława Górzyńska K, Klara Krasińska p[anna?] wikaria, Bogumiła Bogusławska konsyliarka, Salomea Sielnicka K, Joanna Długołęska kons, Anna Teresa Złotnicka, Katarzyna Zabłocka konsyliarka, Magdalena Wilczyńska konsyliarka

Or.: A. Cap. Luzy O 48 KZKG XXXV Majętność Strzyżewo II: 1751-1793, k. 71

105.

24 VII 1752, bez miejsca [Gniezno?]

Zadośćuczynienie Teresy Ludwiny Karszewskiej ksieni i konwentu Wawrzyńcowi Łojewskiemu dzierżawcy dóbr Woźniki za straty spowodowane gradem. 
Papier, k. 1, j. polski

Podpisy: Ludwina Karszewska ksieni konwentu G, Świętosława Górzyńska konsyliarka, Józef Przybyszewski jako przyjaciel proszony $\mathrm{mp}$

Or.: A. Cap. Luzy O 51 KZKG XXXVIII Majętność Woźniki 1575-1796, k. 117

106.

27 VIII 1752, Gniezno

Nadanie Teresy Ludwiny Karszewskiej ksieni i konwentu dla Wojciecha Pietrzaka - prawo na chałupę i role za czynsz w wysokości 70 tynfów od $1753 \mathrm{r}$.

Papier, k. 2, j. polski

Podpisy: Ludwina Karszewska ksieni konwentu gnizińskiego, Antonina Prądzyńska konsyliarka, Rozalia Łącka Konsyliarka, Świętosława Górzyńska konsyliarka, Klara Krasińska wikaria, Bogumiła Bogusławska konsyliarka, Salomea Sielnicka K, Joanna Długołęska kons, Anna Teresa Złotnicka, Katarzyna Zabłocka kons, Magdalena Wilczyńska K

Or.: A. Cap. Luzy O 50 KZKG XXXVII Majętność Winiary 1557-1799, k. 73

107.

27 VIII 1752, Gniezno

Teresa Wiktoria Wyganowska ksieni podpisuje się na kopii aktu ksieni Ludwiny Karszewskiej, która nadała Wojciechowi Pietrzakowi prawo na chałupę w Winiarach w zamian za czynsz i potwierdza jego odbiór w latach 1755, 1757-1761.

Papier, k. 2, j. polski

Podpisy: WW [Wiktoria Wyganowska] ksieni K G, Wiktoria Wyganowska ksieni K G Uwaga: Sześć dopisek o odebraniu czynszu ręką Wyganowskiej i jej podpisy

Or.: A. Cap. Luzy O 50 KZKG XXXVII Majętność Winiary 1557-1799, k. 74

108.

przed 1 VIII 1753, Gniezno

Kontrakt Agaty Rozalii Łąckiej ksieni i konwentu z Ludwikiem Szoberem majstrem na kopanie rudy w lesie gołąbkowskim.

Papier, k. 1, j. polski

Podpis: Rozalia Łącka ksieni K G

Or:: A. Cap. Luzy O 33 KZKG XX Majętności Gołąbki, Piszcz, Łomno, Ochodza 1602-1801, k. 64

109.

13 VII 1753, Gniezno

Kontrakt ksieni Agaty Rozalii Łąckiej i konwentu z Janem i Katarzyną na budowę domu w Piszczu i zwolnienie ich z czynszów na sześć lat.

Papier, k. 1, j. polski

Podpis: Rozalia Łącka ksieni K G

Or.: A. Cap. Luzy O 33 KZKG XX Majętności Gołąbki, Piszcz, Łomno, Ochodza 1602-1801, k. 65 


\section{0.}

\section{VI 1753, Gniezno}

Kontrakt Agaty Rozalii Łąckiej ksieni i konwentu na jednoroczną dzierżawę dóbr w Strzyżewie.

Papier, k. 2, j. polski

Podpisy: Rozalia Łącka ksieni konwentu G, Świętosława Gorzyńska konsyliarka, Klara Krasińska konsyliarka, B[ogumiła] Bogusławska wikaria, Salomea Sielnicka K, Joanna Długołęska kons, Anna Teresa Złotnicka, Katarzyna Zabłocka konsyliarka, Magdalena Wilczyńska konsyliarka Or.: A. Cap. Luzy O 48 KZKG XXXV Majętność Strzyżewo II: 1751-1793, k. 6

\section{1.}

\section{VII 1753, Gniezno}

Kontrakt Agaty Rozalii Łąckiej ksieni i konwentu z Wojciechem Astrakowskim na sześcioletnie pozyskiwanie ról w dobrach klarysek Piszcz, zbudowanie osady, w zamian za co otrzyma zwolnienie z płacenia czynszów.

Papier, k. 1, j. polski

Podpis: Rozalia Łącka ksieni K G

Or.: A. Cap. Luzy O 33 KZKG XX Majętności Gołąbki, Piszcz, Łomno, Ochodza 1602-1801, k. 66

\section{2.}

\section{IX 1753, Gniezno}

Agata Rozalia Łącka ksieni i konwent nadają kowalowi Stanisławowi Zielińskiemu prawo budowy na gruncie klarysek z trzyletnim zwolnieniem od czynszu.

Papier, k. 2, j. polski

Podpisy: Rozalia Łącka ksieni konwentu gnieźnińskiego K G, Antonina Prądzyńska konsyliarka, Świętosława Górzyńska konsyliarka, Ludwinia Karszewska konsyliarka, Klara Krasińska konsyliarka, Bogumiła Bogusławska wikaria, Salomea Sielnicka, Katarzyna Zabłocka, Magdalena Wilczyńska konsyliarki, Konstancja Paruszewska Z, Jadwiga Kaczorowska Z, Agnieszka Konarzewska, Weronika Gorlewska sekretarka, X Bazyli Słącki penitencjarz panieński mp

Or.: A. Cap. Luzy O 32 KZKG XIX Grzybowo 1614-1833, k. 41

\section{3.}

\section{VII 1754, Gniezno}

Kontrakt Agaty Rozalii Łąckiej ksieni i konwentu z Janem Kizorem na 12-letnie pozyskiwanie ról w dobrach klarysek Ochodza i zbudowanie osady.

Papier, k. 1, j. polski

Podpis: Rozalia Łącka ksieni K G

Or.: A. Cap. Luzy O 33 KZKG XX Majętności Gołąbki, Piszcz, Łomno, Ochodza 1602-1801, k. 67

\section{4.}

\section{VI 1755, Woźniki}

Kontrakt Agaty Rozalii Łąckiej ksieni i konwentu z Wawrzyńcem i Jadwigą Łojewskimi na jednoroczną dzierżawę dóbr Woźniki. 
Papier, k. 2, j. polski

Podpisy: Rozalia Łącka ksieni konwentu gniesnińskiego, Świętosława Górzyńska konsyliarka, Ludwina Karszewska konsyliarka, Klara Krasińska konsyliarka, B.[ogumiła] Bogusławska wikaria K, Salomea Sielnicka K, Joanna Długołęska kons, Anna Zabłocka konsyliarka, Konstancja Paruszewska konsyliarka, Wiktoria Wyganowska konsyliarka, Jadwiga Kaczorowska konsyliarka, Agnieszka Konarzewska K, Weronika Gorlewska sekretarka

Or.: A. Cap. Luzy O 51 KZKG XXXVIII Majętność Woźniki 1575-1796, k. 123

\section{5.}

27 VI 1755, Gniezno

Kontrakt Agaty Rozalii Łąckiej ksieni i konwentu ze Stanisławem i Katarzyną na jednoroczną dzierżawę dóbr Grotkowo.

Papier, k. 1, j. polski

Podpisy: Rozalia Łącka ksieni K G, Świętosława Górzyńska konsyliarka, Ludwinia Karszewska konsyliarka, Klara Krasińska konsyliarka, Bogumiła Bogusławska konsyliarka, Salomea Sielnicka konsyliarka, Joanna Długołęska konsyliarka, Katarzyna Zabłocka konsyliarka, Konstancja Paruszewska konsyliarka, Wiktoria Wyganowska konsyliarka, Jadwiga Kaczorowska konsyliarka, Weronika Gorlewska sekretarka

Or.: A. Cap. Luzy O 34 KZKG XX Majętność Grotkowo 1589-1798, k. 32

\section{6.}

8 XIII 1755, bez miejsca [Gniezno?]

Kontrakt Agaty Rozalii Łąckiej ksieni i konwentu z rybakiem Tomaszem na roczną dzierżawę jeziora w dobrach klarysek.

Papier, k. 1, j. polski

Podpis: Rozalia Łącka ksieni konwentu gnieźnińskiego

Or.: A. Cap. Luzy O 18 KZKG V Majętności. Generalia 1646-1834, k. 11

117.

19 XI 1756, Gniezno

Teresa Wiktoria Wyganowska ksieni i konwent wynajmuje wdowie domek z obowiązkiem płacenia podatków i czynszów oraz napraw.

Papier, k. 1, j. polski

Pieczęć okrągła wyciśnięta przez papier

Podpisy: Wiktoria Wyganowska ksieni K G, Rolia [!] Łącka konsyliarka, Świętosława Górzyńska konsyliarka, Ludwinia Karszewska kon, Klara Krasińska kon, Bogumiła Bogusławska konsyliarka, Salomea Sielnicka K, Katarzyna Zabłocka K, Magdalena Wilczyńska K, Konstancja Paruszewska kon, Jadwiga Kaczorowska kon, Agnieszka Konarzewska

Or.: A. Cap. Luzy O 29 KZKG XVI Posiadłości ziemskie w Gnieźnie 1543-1772, k. 16

118.

19 XI 1756, Gniezno

Teresa Wiktoria Wyganowska ksieni i konwent nadaje grunt i ogród przy kościele św. Piotra w wieczystą dzierżawę Michałowi i Mariannie Lewandowiczom. 
Papier, k. 2, j. polski

Pieczęć okrągła wyciśnięta przez papier

Podpisy: Wiktoria Wyganowska ksieni K G, Rozalia Łącka konsyliarka, Świętosława Górzyńska K, Ludwinia Karszewska konsyliarka, Klara Krasińska kon, Bogumiła Bogusławska konsyliarka, Salomea Sielnicka K, Katarzyna Zabłocka Kon, Magdalena Wilczyńska K, Konstancja Paruszewska Kon, Jadwiga Kaczorowska Kon, Agnieszka Konarzewska

Or.: A. Cap. Luzy O 30 KZKG XVII Spór o ogród z proboszczem kościoła św. Piotra w Gnieźnie 1442-1764, k. 46

119.

19 XI 1756, Gniezno

Teresa Wiktoria Wyganowska ksieni i konwent nadaje grunt i ogród przy kościele św. Piotra w wieczystą dzierżawę Benedyktowi i Zofii Chwiłowiczom.

Papier, k. 2, j. polski

Pieczęć okrągła wyciśnięta przez papier

Podpisy: Wiktoria Wyganowska ksieni K G, Rozalia Łącka K, Świętosława Górzyńska K, Ludwinia Karszewska Konsyliarka, Klara Krasińska K, Bogumiła Bogusławska K, Salomea Sielnicka K, Katarzyna Zabłocka Konsyliarka, Magdalena Wilczyńska Kons, Konstancja Paruszewska Z, Jadwiga Kaczorowska Z, Agnieszka Konarzewska Z

Or.: A. Cap. Luzy O 30 KZKG XVII Spór o ogród z proboszczem kościoła św. Piotra w Gnieźnie 1442-1764, k. 47.

120.

\section{III 1757, Gniezno}

Kontrakt Teresy Wiktorii Wyganowskiej ksieni z cieślą Michałem Chochlewiczem na cięcie bloków drewnianych po łokci 20 długości.

Papier, k. 1, j. polski

Podpis: W.[iktoria] Wyganowska X K G

Uwaga: Dopisek najprawdopodobniej ręką Wyganowskiej: „na ten kontrakt daję złotych polskich trzydzieści 3".

Or.: A. Cap. Luzy O 15 KZKG Generalia 1576-1820, k. 17

\section{1.}

7 VI 1757, Gniezno

Kontrakt Teresy Wiktorii Wyganowskiej ksieni i konwentu z Ludwikiem Szoberem majstrem na kopanie rudy w lesie gołąbkowskim, potwierdzenie odbioru 2 czerwonych złotych.

Papier, k. 1, j. polski

Podpis: W[iktoria] Wyganowska X K G

Uwaga: Dokument pisany przez Wyganowską

Or.: A. Cap. Luzy O 33 KZKG XX Majętności Gołąbki, Piszcz, Łomno, Ochodza 1602-1801, k. 70 


\section{2.}

\section{VI 1757, Woźniki}

Kontrakt Teresy Wiktorii Wyganowskiej ksieni i konwentu z Wawrzyńcem i Jadwigą Łojewskimi na trzyroczną dzierżawę dóbr Woźniki.

Papier, k. 2, j. polski

Podpisy: Wiktoria Wyganowska ksieni konwentu gnieźnińskiego, Świętosława Górzyńska K, Lidwina Karszewska konsyliarka, Klara Krasińska konsyliarka, Bogumiła Bogusławska K, Salomea Sielnicka K, Anna Złotnicka Z S K, Katarzyna Zabłocka K wikaria, Konstancja Paruszewska, Jadwiga Kaczorowska K, Agnieszka Konarzewska K

Or.: A. Cap. Luzy O 51 KZKG XXXVIII Majętność Woźniki 1575-1796, k. 125

\section{3.}

\section{XI 1757, Gniezno}

List ksieni Teresy Wiktorii Wyganowskiej do księdza kanonika łowickiego Janickiego w sprawie wyrażenia zgody na ślub poddanej klasztoru z poddanym Kapituły Metropolitalnej.

Papier, k. 2, j. polski

Pieczęć wyciśnięta na papierze na podkładzie z wosku

Podpis: Wiktoria Wyganowska ksieni konwentu g

Or.: A. Cap. Luzy O 24 KZKG XI Poddani 1583-1786, k. 16

\section{4.}

11 VII 1759, Gniezno

Kontrakt Teresy Wiktorii Wyganowskiej ksieni i konwentu ze Piotrem Płonczyńskim na trzyletnią dzierżawę dóbr Grotkowo.

Papier, k. 2, j. polski

Podpisy: Wiktoria Wyganowska ksieni K G, Klara Krasińska, Weronika Gorlewska, Eufrozyna Szeliska, Piotr Płonczyński

Or.: A. Cap. Luzy O 34 KZKG XX Majętność Grotkowo 1589-1798, k. 33

\section{5.}

23 V 1762, bez miejsca [Gniezno, Swarzędz]?

Anna Teresa Złotnicka klaryska potwierdziła odbiór prowizji należnej jej od starszych gminy żydowskiej w Swarzędzu.

Papier, k. 1, j. polski

Podpis: Teresa Złotnicka zakonnica S M Klary Gn k

Uwaga: Dokument pisany jej ręką

Or.: A. Cap. Luzy O 31 KZKG XVIII Stosunki z Żydami gnieźnieńskimi 1534-178, k. 45.

\section{6.}

20 VII 1762, Gniezno

Kontrakt Marianny Klary Krasińskiej ksieni i konwentu ze Stanisławem Trąmpczyńskim na jednoletnią dzierżawę dóbr Grotkowo. 
Papier, k. 2, j. polski

Podpisy: Klara Krasińska ksieni K G, Rozalia Łącka, Ludwinia Karszewska, Bogumiła Bogusławska, Salome Sielnicka, Magdalena Wilczyńska, Róża Szczytnicka, Agnieszka Konarzewska

Or.: A. Cap. Luzy O 34 KZKG XX Majętność Grotkowo 1589-1798, k. 40

\section{7.}

6 VIII 1763, Gniezno

Marianna Klara Krasińska ksieni z konwentem zezwala Mariannie Doruchowskiej na kupno domku stojącego na gruncie klasztoru.

Papier, k. 1, j. polski

Podpis: Klara Krasińska ksieni konwentu G

Or.: A. Cap. Luzy O 32 KZKG XIX Grzybowo 1614-1833, k. 48.

\section{8.}

bez daty dziennej 1763 , Gniezno

Kontrakt Marianny Klary Krasińskiej ksieni i konwentu z Janem Izbińskim na jednoroczną dzierżawę dóbr Gołąbki.

Papier, k. 1, j. polski

Podpisy: Klara K[rasińska] X K G Z M S K, Jan Izbinski

Uwaga: na verso: „Tego kontraktu nie aprobujemy jako z krzywdą WW. panien gnieznienskich uczynionego. Działo się w Gnieźnie podczas wizyty”.

Podpisy: X [ksiądz] Michał Stalkiewicz prowincjał, X [ksiądz] Karol Bonawentura Gorczynski sekretarz $\mathrm{i}$ asystent prowincyi

Or.: A. Cap. Luzy O 33 KZKG XX Majętności Gołąbki, Piszcz, Łomno, Ochodza 1602-1801, k. 73

129.

26 II 1764, Gniezno

Kontrakt Marianny Klary Krasińskiej ksieni i konwentu z Olędrami na zasiedlenie pustkowia Ochodza.

Papier, k. 1, j. polski

Pieczęć okrągła wyciśnięta na papierze na ozdobnym kustodium

Podpisy: Klara Krasińska X K G Michał Izbinski miecznik sochaczewski i komisarz PKG.

Or:: A. Cap. Luzy O 33 KZKG XX Majętności Gołąbki, Piszcz, Łomno, Ochodza 1602-1801, k. 74

130.

bez daty dziennej i miejsca 1764, [Gniezno?]

Kontrakt Marianny Klary Krasińskiej ksieni i konwentu z Antonim i Agnieszką Straszewskimi na trzyletnią dzierżawę dóbr w Strzyżewie.

Papier, k. 2, j. polski

Podpisy: Klara Krasińska ksieni K G, Ludwina Karszewska konsyliarka, Antoni Straszewski, Agnieszka Straszewska

Or.: A. Cap. Luzy O 48 KZKG XXXV Majętność Strzyżewo II: 1751-1793, k. 33 


\section{1.}

21 VIII 1765, Gniezno

Rozalia Konstancja Paruszewska ksieni z konwentem przekazuje wójtowi grzybowskiemu sprawę uregulowania roszczeń finansowych i zezwala na sprzedaż domostwa Doruchowskiej.

Papier, k. 1, j. polski

Podpis: Konstancja Paruszewska X K G

Uwaga: Dokument pisany przez ksienię

Or.: A. Cap. Luzy O 32 KZKG XIX Grzybowo 1614-1833, k. 58

\section{2.}

8 X 1765, Gniezno

Rozalia Konstancja Paruszewska ksieni z konwentem zezwala Janowi i Konstancji Kęcińskim na zakup domu stojącego na gruncie klasztoru w Kostrzynie.

Papier, k. 1, j. polski

Podpis: Konstancja Paruszewska ksieni K G

Or.: A. Cap. Luzy 39 KZKG XXVI Kostrzyn i Strumiany IV: 1745-1766, k. 75

133.

16 X 1765 , Kostrzyn

Kontrakt Marianny Klary Krasińskiej ksieni i konwentu z Antonim i Małgorzatą Siekackimi na dzierżawę jednoroczną dwóch gościńców i browaru w Kostrzynie.

Papier, k. 2, j. polski

Podpis: Klara Krasińska X K G, Antoni Siekacki swoim i Małgorzaty swojej małżonki imieniem Or:: A. Cap. Luzy 39 KZKG XXVI Kostrzyn i Strumiany IV: 1745-1766, k. 57.

\section{4.}

11 II 1766, Gniezno

Kontrakt Rozalii Konstancji Paruszewskiej ksieni i konwentu z mistrzem Krzysztofem Golesznerem na przetarcie bloków drewna z borów klarysek.

Papier, k. 1, j. polski

Podpis: K[onstancja] P[aruszewska] ksieni K G

Or.: A. Cap. Luzy O 33 KZKG XX Majętności Gołąbki, Piszcz, Łomno, Ochodza 1602-1801, k. 78

135.

8 XI 1766, Gniezno

Marianna Klara Krasińska ksieni potwierdza, że odebrała od archidiakona i oficjała gnieźnieńskiego sumę 124 zł i 18 gr za kawałki srebra i miedzi z połamanej monstrancji z kościoła w Strzyżewie sprzedane w Warszawie.

Papier, k. 2, j. polski

Podpis: „Niżej podpisana swym i całego konwentu gnieźnieńskiego imieniem zeznaję” 
Uwaga: Dalej dokument zniszczony, ubytek dolnej części karty, na której zapewne podpisy i być może pieczęć, gdyż na brzegu zachowane ślady po wosku.

Or.: A. Cap. Luzy O 48 KZKG XXXV Majętność Strzyżewo II: 1751-1793, k. 36

\section{6.}

5 VII 1768, bez miejsca [Gniezno]?

Kontrakt Marianny Klary Krasińskiej ksieni na angaż Józefa Wockowskiego jako ekonoma dóbr Piekary, Obora, Winiary, Gołąbki, Krzyszczewo, Żerniki.

Papier, k. 2, j. polski

Podpis: Klara Krasińska X K G

Or.: A. Cap. Luzy O 18 KZKG V Majętności. Generalia 1646-1834, k. 15

137.

24 VI 1768, Gniezno

Kontrakt Marianny Klary Krasińskiej ksieni i konwentu z Antonim i Agnieszką Straszewskimi na trzyletnią dzierżawę dóbr w Strzyżewie.

Papier, k. 2, j. polski

Podpisy: Klara Krasińska X K G Antoni Straszewski mp

Or.: A. Cap. Luzy O 48 KZKG XXXV Majętność Strzyżewo II: 1751-1793, k. 38

138.

2[3 lub 9] VII 1768, Gniezno

Kontrakt Marianny Klary Krasińskiej ksieni i konwentu na dzierżawę dóbr Grotkowo.

Papier, k. 2, j. polski

Podpis: Klara Krasińska X K G

Or.: A. Cap. Luzy O 34 KZKG XX Majętność Grotkowo 1589-1798, k. 54

139.

30 VII 1768, Gniezno

Ugoda Marianny Klary Krasińskiej ksieni i konwentu w sprawie roszczeń dotyczących dzierżawy dóbr Grotkowo.

Papier, k. 2 j. polski

Podpis: Klara Krasińska X K G

Or.: A. Cap. Luzy O 34 KZKG XX Majętność Grotkowo 1589-1798, k. 55.

140.

18 III 1770, Gniezno

Kontrakt Marianny Klary Krasińskiej ksieni i konwentu z Kasprem Leinweberem mistrzem ciesielskim na wystawienie furty.

Papier, k. 2, j. polski

Podpis: Klara Krasińska ksieni 
Uwagi: Pod kontraktem informacja o wydatkach pieniężnych i w naturaliach do tej umowy najprawdopodobniej pisane przez ksienię Krasińską

Or.: A. Cap. Luzy O 15 KZKG II Generalia 1576-1820, k. 23

\section{1.}

\section{VI 1771, Gniezno}

Kontrakt Katarzyny Elżbiety Rzeszotarskiej i konwentu z Antonim i Agnieszką Straszewskimi na trzyletnią dzierżawę dóbr w Strzyżewie.

Papier, k. 2, j. polski

Podpisy: Elżbieta Rzeszotarska X, Ludwina Karszewska K, Konstancja Paruszewska K, Klara Kasińska [!] K, Magdalena Wilczyńska K, Teresa Baranowska K W, Weronika Gorlewska K, Honorata Belęcka K, Brygida Zawadzka K, F.[ranciszka] Frezerówna K, Antoni Straszewski mp Or.: A. Cap. Luzy O 48 KZKG XXXV Majętność Strzyżewo II: 1751-1793, k. 39

\section{2.}

\section{VI 1771, Gniezno}

Kontrakt Katarzyny Elżbiety Rzeszotarskiej i konwentu z Antonim i Agnieszką Straszewskimi na trzyletnią dzierżawę dóbr w Strzyżewie.

Papier, k. 1, j. polski

Podpisy: Elżbieta Rzeszotarska X, Antoni Straszewski mp

Or.: A. Cap. Luzy O 48 KZKG XXXV Majętność Strzyżewo II: 1751-1793, k. 40

\section{3.}

\section{XI 1771, Gniezno}

Katarzyna Elżbieta Rzeszotarska ksieni wydaje Katarzynie Wilczewskiej zgodę na budowanie się na gruncie klasztornym.

Papier, k. 1, j. polski

Pieczęć okrągła wyciśnięta przez papier na zagięciu karty

Podpisy: Elżbieta Rzeszotarska X K G, trzymaną ręką Katarzyna Wilczewska

Or.: A. Cap. Luzy O 29 KZKG XVI Posiadłości ziemskie w Gnieźnie 1543-1772, k. 29

\section{4.}

16 XI 1772, Gniezno

Ugoda Katarzyny Elżbiety Rzeszotarskiej ksieni i konwentu z Mateuszem Głowackim w sprawie tarcicy i drewna rżniętego na gruncie konwentu w Strzyżewie.

Papier, k. 1, j. polski

Podpisy: Elżbieta Rzeszotarska X K G, Mateusz Głowacki

Or.: A. Cap. Luzy O 48 KZKG XXXV Majętność Strzyżewo II: 1751-1793, k. 42

\section{5.}

27 VI 1772, Gniezno

Ugoda Katarzyny Elżbiety Rzeszotarskiej ksieni i konwentu z Antonim Berkiem Gostyńskim co do dzierżawy dóbr Grodkowa z zaszłych pretensji. 
Papier, k. 2, j. polski

Podpisy: Elżbieta Rzeszotarska X K G, Klara Krasnienska [!], Antoni Berk Gostyński

Uwaga: Także podpisy dwóch przyjaciół Gostyńskiego, świeckich

Or.: A. Cap. Luzy O 34 KZKG XX Majętność Grotkowo 1589-1798, k. 97

\section{6.}

19 XI 1773, Gniezno

Ugoda Katarzyny Elżbiety Rzeszotarskiej ksieni i konwentu z małżeństwem Siekackimi w sprawie wieczystego użytkowania przez klasztor pewnego ogrodu.

Papier, k. 1, j. polski

Podpisy: Elżbieta Rzeszotarska X K G, Antoni i Małgorzata Siekacka swoim i małżonki swojej imieniem mp

Or.: A. Cap. Luzy 39 KZKG XXVI Kostrzyn i Strumiany IV: 1745-1766, k. 95.

147.

\section{X 1774, Gniezno}

Katarzyna Elżbieta Rzeszotarska ksieni napisała do Jana Sztemborskiego w sprawie sprzedaży pewnego domu.

Papier, k. 1, j. polski

Podpis: W[ielmożna?] M[ości?] P[anna] życzliwa i w Bogu kochająca E[lżbieta] Rzeszotarska X K G

Uwaga: List pisany ręką ksieni; karta przycięta zarówno w szerokości, jak i długości

Or.: A. Cap. Luzy O 32 KZKG XIX Grzybowo 1614-1833, k. 67

\section{8.}

4 VI 1775, bez miejsca [Gniezno?]

Marianna Klara Krasińska ksieni potwierdza odbiór prowizji od 1000 zł jako dochodu na przyszły rok 1776.

Papier, k. 1, j. polski

Podpis: Klara Krasienska [!] Z S M K

Uwaga: Pod aktem: „Ja niży na podpisie zeznaję tym skryptem jakom odebrała z konwentu prowizyją od tysiąca złotych polskich złotych piędziesiąt diko 50 na rok przyszły to jest 1776 na S Jan Krzyciel [!] należącą odebrałam w roku 1775 dnia 4 czerwca w potrzebie na co się podpisuje własną ręką"

Or.: A. Cap. Luzy O 22 KZKG IX Rachunki, pokwitowania 1573-1834, k. 48

\section{9.}

\section{VIII 1776, Gniezno}

Marianna Klara Krasińska ksieni i konwent daje Walentemu Gabryskowi trzyletni kontrakt na mieszkanie w Krzyszczewie w zamian za czynsz w wysokości 100 i 120 tynfów na kolejny rok.

Papier, k. 1, j. polski

Podpis: K[lara] K[rasińska] X K G

Or.: A. Cap. Luzy O 42 KZKG XXXIX Majętność Krzyszczewo 1611-179, k. 17 
150.

18 I 1778, Gniezno

Anna Teresa Baranowska ksieni i konwent ogłaszają nowe prawo dla wsi Miniszewo.

Papier, k. 2, j. polski

Pieczęć okrągłą odciśnięta na papierze na ozdobnym kustodium

Podpisy: Teres Baranowska ksieni K G, Klara Krasińska konsyliarka, Magdalena Wilczyńska konsyliarka, Elżbieta Rzeszotarska eks ksieni K, Weronika Gorlewska wikaria i K, Honorata Belęcka K, Eufrozyna Szeliska K, Franciszka Frezerówna K, Jozafata Rokossowska K, Zofia Kraszkowska K Or.: A. Cap. Luzy O 44 KZKG XXXI Majętność Miniszewo II: 1725-1795, k. 48

151.

25 VI 1779, Grotkowo

Kontrakt Anny Teresy Baranowskiej ksieni i konwentu z Jaraczewskimi na trzyletnią dzierżawę dóbr Grotkowo.

Papier, k. 2, j. polski

Podpisy: Teresa Baranowska ksieni K G, Elżbieta Rzeszotarska, Eufrozyna Szeliska, Zofia Kraszkowska, Konstancja Jaraczewska

Or:: A. Cap. Luzy O 34 KZKG XX Majętność Grotkowo 1589-1798, k. 71

152.

17 IV 1782, Gniezno

Kontrakt Katarzyny Elżbiety Rzeszotarskiej ksieni z Warzyńcem Wietrzyńskim na palenie potażu na użytek konwentu w lasach gołąbkowskich.

Papier, k. 1 polski

Podpis: Elżbieta Rzeszotarska X K G mp

Or.: A. Cap. Luzy O 33 KZKG XX Majętności Gołąbki, Piszcz, Łomno, Ochodza 1602-1801, k. 85

153.

24 VII 1785, Gniezno

Kontrakt Katarzyny Elżbiety Rzeszotarskiej ksieni z malarzem Ignacym Ocieszalskim na prace w kaplicy.

Papier, k. 1 polski

Podpis: Elżbieta Rzeszotarska X K G mp

Or.: A. Cap. II 865 Renowacja kaplicy klarysek 1766-1785, k. 5

154.

21 X 1787, Gniezno

Ewa Zofia Kraszkowska ksieni prosi Kapitułę Metropolitalną o zgodę na dalsze pobieranie drewna opałowego z lasu Jezierzach.

Papier, k. 2, j. polski

Podpis: Z[ofia] Kraszkowska X K G 
Uwaga: Pisany ręką Kraszkowskiej. Dokument w kopercie z pieczęcią okrągłą odciśniętą w czerwonym wosku

Or.: A. Cap. Luzy O 27 KZKG XIV Listy 1696-1800, k. 5

\section{5.}

\section{III 1788, Gniezno}

Ugoda Ewy Zofii Kraszkowskiej ksieni i konwentu z księdzem Michałem Józefem Neringiem proboszczem kcyńskim na mocy której przejął on od konwentu prawa do dziesięciny z ról kcyńskich.

Papier, k. 1, j. polski

Podpisy: Zosia Kraszkowska X K G, Michał Jozef Nering mp

Or.: A. Cap. Luzy O 28 KZKG XV Dziesięcina z Kcyni 1418-1799, k. 79

\section{6.}

10 VII 1797, Gniezno

Kontrakt Ludwiki Franciszki Frezerówny ksieni i konwentu z Kazimierzem Liszowskim mistrzem ciesielskim na wykonanie prac w klasztorze.

Papier, k. 2, j. polski

Podpis: Franciszka Frezerówna ksieni K G

Or.: A. Cap. Luzy O 32 KZKG XIX Grzybowo 1614-1833, k. 79

157.

25 V 1809, Gniezno

List Rozalii Serafiny Zagajewskiej ksieni klarysek do kanonika gnieźnieńskiego, prokuratora kapituły metropolitalnej Marcina Dunina z podziękowaniem za projekt rozłożenia na cztery raty sumy $752 \mathrm{zł}$.

Papier, k. 1, j. polski

Ślady po pieczęci lakowej na papierze

Podpis: Serafina Zagajewska X K G

Uwaga: List pisany przez ksienię

Or.: A. Cap. Luzy O 19 KZKG VI Kompetencje 1777-1824, k. 11

158.

6 VII 1809, Gniezno

List Rozalii Serafiny Zagajewskiej ksieni klarysek do kanonika gnieźnieńskiego, prokuratora kapituły metropolitalnej Marcina Dunina z informacją o tym, że nie może zapłacić raty 188 zł polskich długu, bo musiała zapłacić podatek podymny.

Papier, k. 2, j. polski

Pieczęć lakowa odciśnięta na papierze, zachowana szczątkowo

Podpis: Serafina Zagajewska X K G

Uwaga: pisany przez ksienię

Or.: A. Cap. Luzy O 19 KZKG VI Kompetencje 1777-1824, k. 12 
159.

10 VIII 1809, Gniezno

List Rozalii Serafiny Zagajewskiej ksieni klarysek do kanonika gnieźnieńskiego, prokuratora kapituły metropolitalnej Marcina Dunina z informacją o przesłaniu 20 talarów na poczet długu.

Papier, k. 2, j. polski

Pieczęć lakowa odciśnięta na papierze, zachowana szczątkowo

Podpis: Serafina Zagajewska X G

Uwaga: List pisany przez ksienię

Or.: A. Cap. Luzy O 19 KZKG VI Kompetencje 1777-1824, k. 13

160.

17 XI 1809, Gniezno

List Rozalii Serafiny Zagajewskiej ksieni klarysek do kanonika gnieźnieńskiego, prokuratora kapituły metropolitalnej Marcina Dunina z informacją o zapłacie podwójnego podatku podymnego i informacji o przesłaniu zaległej raty 188 zł polskich.

Papier, k. 1, j. polski

Pieczęć lakowa odciśnięta na papierze, zachowana szczątkowo

Podpis: Serafina Zagajewska X K G

Uwaga: pisany przez ksienię

Or.: A. Cap. Luzy O 19 KZKG VI Kompetencje 1777-1824, k. 10

161.

bez daty, między 1831-1833, Gniezno

Róża Aniela Zagajewska ksieni potwierdza odbiór komornego od stolarza Adamkiewicza 25 sierpnia 1831, 10 lipca 1832, 20 lutego 1833, 6 października 1833.

Papier, k. 1, j. polski

Podpis: A[niela] Zagajewska X K G

Or.: A. Cap. Luzy O 22 KZKG IX Rachunki, pokwitowania 1573-1834, k. 66

\section{REFERENCES / BIBLIOGRAFIA}

\section{Źródla}

Archiwum Archidiecezjalne w Gnieźnie

A Cap. Luzy Kapituła Metropolitalna O 14-52.

ACap. II 865 Renowacja kaplicy klarysek 1766-1785.

Dyplomy Gnieźnieńskie

ZKG 3 Księgi wszystkich spraw konwentu gnieźnieńskiego zakonu S. Klary. To jest katalog wszystkich sióstr zakonnych $\mathrm{w}$ tym klasztorze od pamięci ludzkiej professowanych żywych i zmarłych. Przytem inwentarz wszystkich dóbr prowentów także i przywilejów 
tegoż klasztoru za urzędu Wielebnej w Chrystusie Panny, Panny Doroty Bromierskiej, na ten czas Księniej tegoż klasztoru (acz niegodnej) uczynione, i pilnie pisane w roku pańskim 1609.

Archiwum Franciszkanów w Krakowie

Karwacki Alojzy, Materiaty do historii konwentów franciszkańskich Prowincji Polskiej, t. 9, Essen-Gdańsk 1999.

Karwacki Alojzy, Sławniejsi franciszkanie w Polsce. Ich życiorysy i dzieła, Kraków 1922, msp.

\section{Źródła drukowane}

Klasztory karmelitanek bosych w Polsce, na Litwie i Rusi, t. 1-4, wyd. R. Kalinowski, Kraków 1900-1904.

Kronika bernardynek lubelskich 1618-1885, oprac. i wyd. A. Szylar, Lublin 2009.

Kronika wielkopolska, w: Monumenta Poloniae Historica, s.n., t. 7, wyd. B. Kürbis, Warszawa 1970.

Ney Karol, Kronika zakonnic klasztoru św. Klary w Gnieźnie i żywot Jolanty, Leszno 1843.

Pisma Święci Franciszek i Klara z Asyżu wydanie łacińsko-polskie, Kraków-Warszawa 2002.

Kodeks dyplomatyczny Wielkopolski, t. 1, wyd. I. Zakrzewski, Poznań 1877.

\section{Opracowania}

Atlas historyczny Polski. Wielkopolska w drugiej połowie XVI wieku, cz. 2: Komentarz. Indeksy, red. K. Chłapowski, M. Słoń, Warszawa 2017.

Borkowska Małgorzata, Łatanie pamięci (czyli rzecz o klasztornym kronikarstwie retrospektywnym), „Znak”, 47 (1995) s. 103-110.

Borkowska Małgorzata, Nieznana autorka norbertańska z końca XVI wieku, „Nasza Przeszłość", 99 (2003) s. 165-213.

Borkowska Małgorzata, Reforma potrydencka $w$ klasztorze $w$ Strzelnie, „Nasza Przeszłość", 100 (2004) s. 206-217.

Borkowska Małgorzata, Leksykon zakonnic polskich epoki przedrozbiorowej, t. 1: Polska Zachodnia i Pólnocna, Warszawa 2004.

Dzieje Gniezna, red. J. Topolski, Poznań 1976.

Dyplomatyka staropolska, red. T. Jurek, Warszawa 2015.

Formanowicz Leon, Katalog druków polskich XVI-go wieku Biblioteki Kapitulnej w Gnieźnie, Poznań 1930.

Formanowicz Leon, Katalog inkunabułów Biblioteki Kapitulnej w Gnieźnie, z. 1, Poznań 1939.

Gąsiorowska Patrycja, Skład osobowy klasztoru Klarysek w Krakowie do końca XVIII wieku, Kraków 2005.

Głombiowski Karol, Szwejkowska Helena, Książka rękopiśmienna i biblioteka w starożytności i średniowieczu, Warszawa 1968.

Gwioździk Jolanta, Kultura pisma i książi w żeńskich klasztorach dawnej Rzeczpospolitej XVI-XVII w., Katowice 2015.

Jasiński Kazimierz, Przemyst, w: Polski Słownik Biograficzny, t. 28, Kraków-Warszawa, 1984-1985, s. 730-733. 
Joskowski Zbigniew, Katalog starych druków biblioteki franciszkanów w Gnieźnie, Banino 2015.

Katalog poloników XVI wieku Biblioteki Jagiellońskiej, t. 1, red. M. Malicki, E. Zwinogrodzka, Kraków 1992.

Koczerska Maria, Kancelarie i dokumentacja kościelna, w: Dyplomatyka staropolska, red. T. Jurek, Warszawa 2015, s. 339-388.

Korytkowski Jan, Prałaci i kanonicy katedry metropolitalnej od 1000 roku aż do dni naszych podtug źródet archiwalnych, t. 1, Gniezno 1883.

Mączyński Maciej, Językowy obraz XVII-wiecznego klasztoru sióstr norbertanek w Krakowie na Zwierzyńcu, Kraków 2005.

Michalski Maciej, Błogosławiona Jolenta - refleksja historyczno-hagiograficzno-historiozoficzna, w: Franciszkanie konwentualni i klaryski w Wielkopolsce od XIII do XIX wieku, red. T. Janiak i D. Stryniak, Gniezno 2006, s. 71-82.

Michalski Maciej, Kobiety i świętość w żywotach księżnych polskich, Poznań 2004.

Ożóg Krzysztof, Przemyst, w: Piastowie. Leksykon biograficzny, red. S. Szczur, K. Ożóg, Kraków 1999, s. 154-161.

Pietsch Theophila, Zur Geschichte des Breslauer Klarenstiftes im Mittelälter, Breslau 1937.

Pasiciel Stanisław, Zespół klasztorny franciszkanów i klarysek w Gnieźnie, Gniezno 2005.

Pawlak Ireneusz, Graduat klarysek gnieźnieńskich z 1418 roku jako dokument kultury muzycznej Gniezna, „Nasza Przeszłość”, 24 (1966) s. 135-141.

Pax et bonum. Skarby klarysek krakowskich. Katalog wystawy, red. A. Włodarek, Kraków 1999.

Piech Zenon, Średniowieczne pieczęcie tynieckie, w: Benedyktyni tynieccy w średniowieczu. Materiały z Sesji Naukowej Wawel-Tyniec 13-15 X 1994, red. K. Żurowska, Tyniec 1995, s. 121-140.

Przybyłowicz Olga Miriam, Wizytacje klasztoru klarysek w Gnieźnie z lat 1595-1598, w: O rzeczach minionych. Scripta rerum historicarum Annae Rutkowska-Płachcińska oblata, red. M. Młynarska-Kaletynowa, J. Kruppé, Warszawa 2006, s. 247-280

Przybyłowicz Olga Miriam, Archiwalia proweniencji zakonnej diecezji krakowskiej w Centralnym Państwowym Archiwum Historycznym Ukrainy we Lwowie, „Studia Źródłoznawcze", 49 (2011) s. 117-125.

Przybyłowicz Miriam Olga, Archiwalia klarysek gnieźnieńskich w Archiwum Archidiecezji Gnieźnieńskiej, cz. 1: Sprawozdanie z kwerendy w dniach 29-31 VIII 2012 r., „Hereditas Monasteriorum", 1 (2012) s. 456-462.

Przybyłowicz Miriam Olga, Archiwalia klarysek gnieźnieńskich w Archiwum Archidiecezji Gnieźnieńskiej, cz. 2: Sprawozdanie z kwerendy w dniach 9-12 VII 2013 r., „Hereditas Monasteriorum", 3 (2013) s. 552-569.

Przybyłowicz Miriam Olga, „Pamięć obłóczyn kożdy probantki”. Ceremonia obłóczyn w świetle rękopisu Modus suscipiendi novitias ad habitum S. Clarae z 1600 r. z klasztoru klarysek gnieźnieńskich, „Hereditas Monasteriorum”, 3 (2013) s. 179-194.

Przybyłowicz Miriam Olga, Reguła zakonna jest wozem do nieba. Realia życia w klasztorach klarysek w Małopolsce, Wielkopolsce i na Ślasku, Warszawa 2016.

Przybyłowicz Miriam Olga, Rękopis Księgi wszystkich spraw Konwentu Gnieźnieńskiego zakonu S. Klary [...] pilnie pisane w roku pańskim 1609 i jego zawartość, „Hereditas Monasteriorum", 7 (2016) s. 247-263.

Przybyłowicz Olga Miriam, Źródła rękopiśmienne z klasztoru klarysek gnieźnieńskich w Archiwum Archidiecezjalnym w Gnieźnie. Stan wiedzy, prezentacja spuścizny i możliwości badawcze, „Archiwa, Biblioteki i Muzea Kościelne”, 112 (2019) s. 317-336. 
Roguski Jakub, Pieczęcie herbowe ksiąząt Sanguszków od XVI do XVIII w., w: Dawne pieczęcie. Typologia - metody badań - interpretacje, red. Z. Piech, Warszawa 2015, s. 435-476.

Rył Jadwiga, Katalog rękopisów biblioteki katedralnej w Gnieźnie, „Archiwa, Biblioteki, Muzea Kościelne”, 45 (1982) s. 5-201.

Rył Jadwiga, Archiwum i biblioteka w Katedrze Gnieźnieńskiej, Gniezno 1994.

Sawicki Witold, Błogosławiona Jolenta: życia i dzieje kultu, Niepokalanów 1980.

Słownik historyczno-geograficzny województwa poznańskiego w średniowieczu, cz. 1, z. 3, red. A. Gąsiorowski, Wrocław 1986.

Szylar Anna, Liczba zakonnic, skład osobowy i rotacja na urzędach w klasztorze benedyktynek w Sandomierzu w latach 1615-1903, „Nasza Przeszłość”, 102 (2004) s. 287352.

Targosz Karolina, Piórem zakonnicy. Kronikarki w Polsce XVII w. o swoich zakonach i swoich czasach, Kraków 2002.

Trzciński Tadeusz, Katalog rękopisów biblioteki kapitulnej w Gnieźnie aż do początku XVI w., „Roczniki Towarzystwa Przyjaciół Nauk Poznańskiego”, 35 (1910) s. 169320.

Urban Wacław, Stan oświecenia duchowieństwa krakowskiego w wiekach XVI-XVIII, „Przegląd Historyczny”, 74 (1983) z. 3, s. 509-515.

Wiszewski Przemysław, Opactwo benedyktynek w Legnicy (1348/1349-1810). Struktura, funkcjonowanie, miejsce w społeczeństwie, Poznań-Wrocław 2003.

Wiszewski Przemysław, Średniowieczna ślaska pieczęć klasztorna jako środek przekazu informacji (XIII-1.połowa XVI w.), w: Pieczęć w Polsce średniowiecznej i nowożytnej. Zbiór studiów, red. P. Dymmel, Lublin 1998, s. 11-29.

Wojciechowski Leszek, Pieczęcie zakonu paulinów w Polsce do 1630 roku, w: Pieczęć w Polsce średniowiecznej i nowożytnej. Zbiór studiów, red. P. Dymmel, Lublin 1998, s. 39-53.

Wojtkowski Julian, Rekonstrukcja drugiego zeszytu katalogu inkunabułów Biblioteki Kapitulnej w Gnieźnie księdza Leona Formanowicza, Lublin 1969.

Wójcik Marek L., Pieczęcie cystersów jemielnickich do połowy XVI wieku (z zespołu Rep. 85 Archiwum Państwowego we Wrocławiu), w: Pieczęć w Polsce średniowiecznej i nowożytnej. Zbiór studiów, red. P. Dymmel, Lublin 1998, s. 32-37.

\section{Netografia}

Kartoteka słownika języka polskiego XVII i 1. połowy XVIII wieku. 


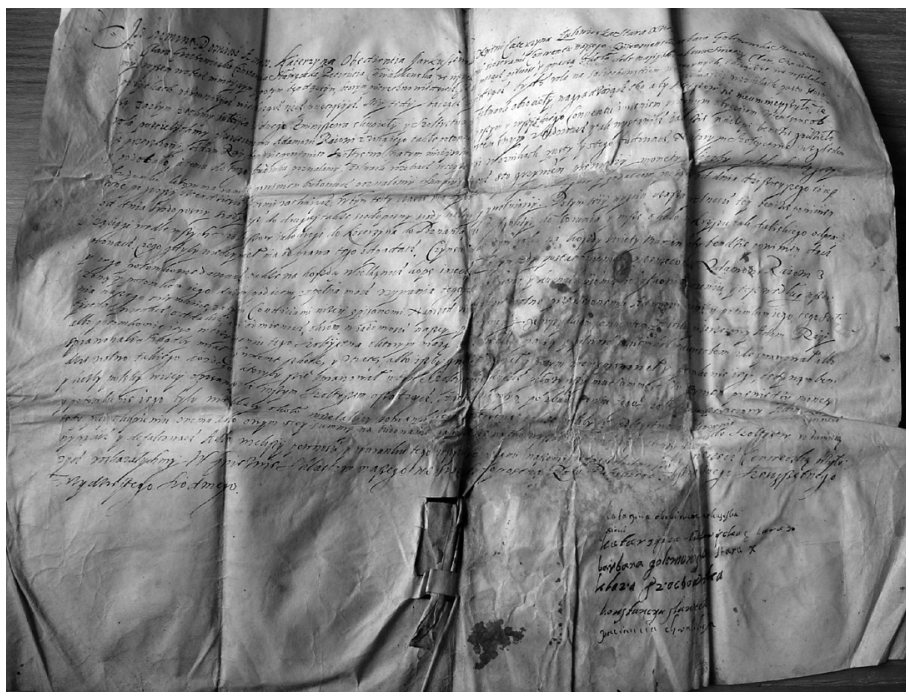

Il. 1. AAG Dyplomy Gn nr 886. 25 lutego 1637 r. Katarzyna Obediencja Arkuszewska/Jarkuszewska ksieni wraz z konwentem nadaje Adamowi Rajowi sołectwo w Woźnikach (fot. Olga Miriam Przybyłowicz)

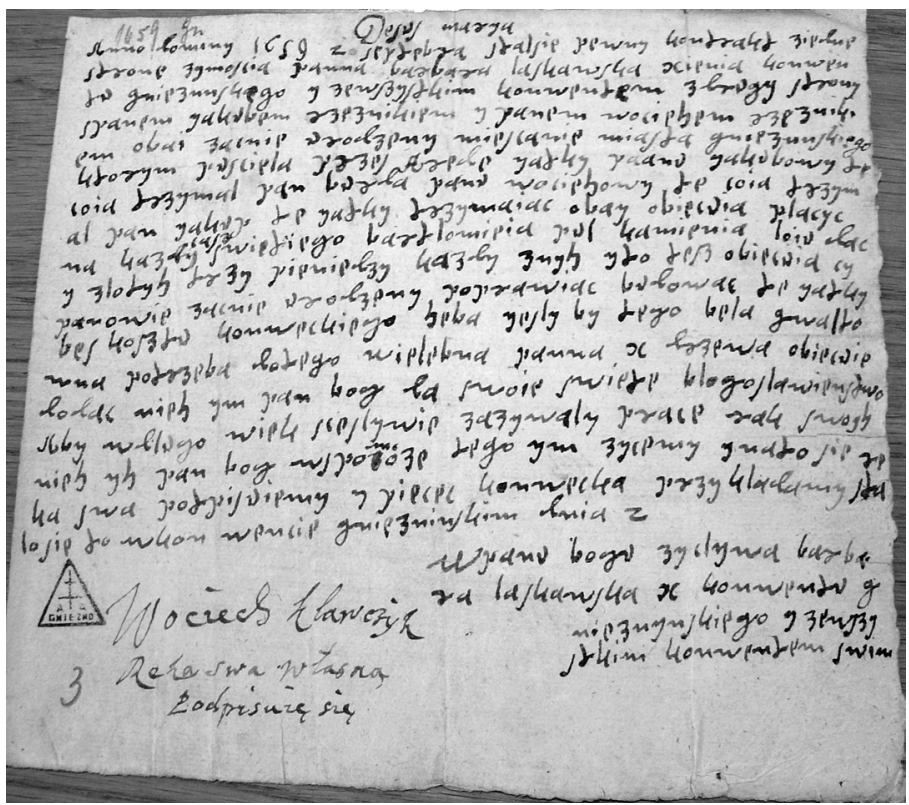

Il. 2 .AAG A. Cap. Luzy O 29 KZKG XVI Posiadłości ziemskie

w Gnieźnie 1543-1772, k. 3.20 września 1659. Kontrakt Barbary Kunegundy

Łaskawskiej/Laskowskiej ksieni i konwentu z Jakubem rzeźnikiem

i Wojciechem Klawczykiem rzeźnikiem na dzierżawę jatek mięsnych w Gnieźnie (fot. Olga Miriam Przybyłowicz) 


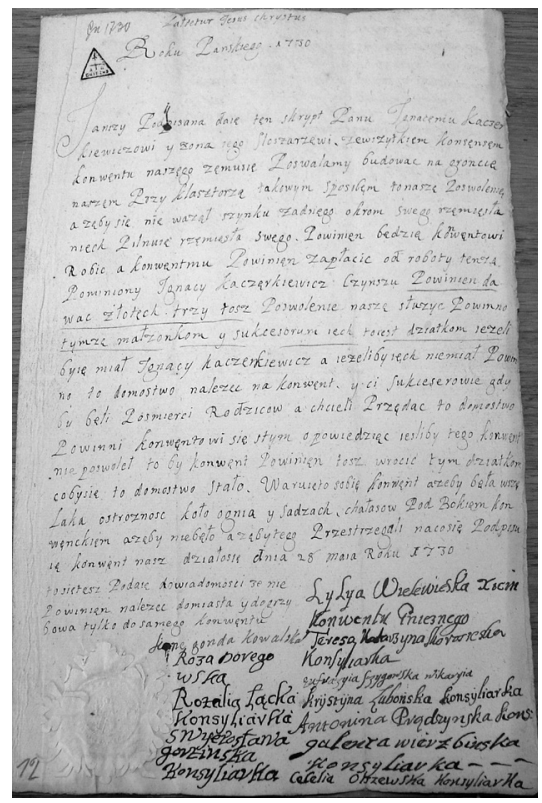

I1. 3. AAG A. Cap. Luzy O 29 KZKG XVI Posiadłości ziemskie

w Gnieźnie 1543-1772, k. 12. 28 maja 1730. Teresa Lilia Wielowiejska ksieni

i konwent zezwalają Ignacemu Kaczerkiewiczowi na budowę domu na gruncie klasztoru (fot. Olga Miriam Przybyłowicz)

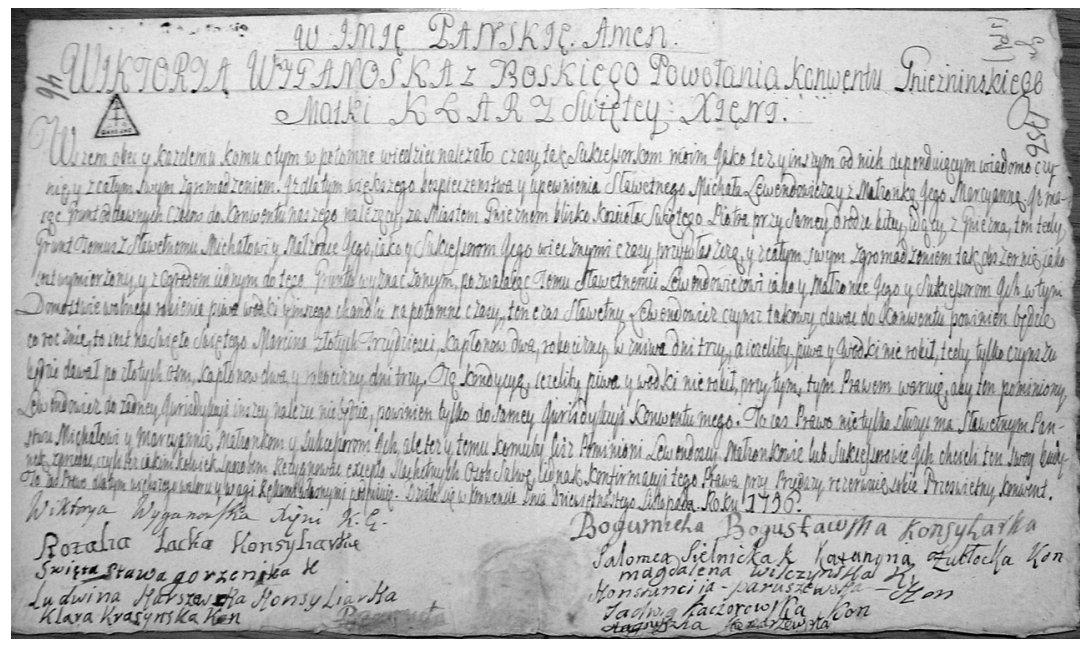

Il. 4. AAG A. Cap. Luzy O 30 KZKG XVII Spór o ogród z proboszczem kościoła św. Piotra w Gnieźnie 1442-1764, k. 46.19 listopada 1756. Teresa Wiktoria Wyganowska ksieni i konwent nadaje grunt i ogród przy kościele św. Piotra w wieczystą dzierżawę Michałowi i Mariannie Lewandowiczom (fot. Olga Miriam Przybyłowicz). 


\title{
DOCUMENTS AND DIPLOMAS OF THE POOR CLARES CONVENT IN GNIEZNO. METHODS OF AUTHENTICATING DOCUMENTS IN THE PRACTICE OF THE CONVENT OF ST. CLARE. INVENTORY
}

\begin{abstract}
The aim of this article is to present and analyse the original files and parchment diplomas of the Poor Clares of Gniezno as regards office practice, including the methods of authenticating documents in the monastery and the degree of literacy of the nuns themselves. The documents are held by the Archdiocese Archives in Gniezno. The material and topical division of archives was also presented. The query covered parchment diplomas from the Gniezno Diplomas collection and documents from loose files kept in the AKM - A Cap section. The loose files - are over 2,500 units and over 4,000 cards. 161 originals were selected, including three parchment diplomas. All of them are included in the Appendix.

Documents were authenticated by signatures and/or stamping a seal by paper or on paper. Two types have survived - one with a pointed-oval shape, indicating the medieval provenance of the seal, which has analogies to the well-known stamps of other female monasteries, e.g. Poor Clares in Skala and Cracow. The second type is a round stamp that began to appear on documents from the second decade of the 18th century.

The dominant language is Polish, moreover, there are individual files written in Latin - mainly letters to clergy, but also to laypeople. Eight material categories were distinguished: contracts - the largest part of the collection 77 , settlements -25 , postings -16 , letters -11 , confirmations -8 , certificates 7 , permits -7 , others -10 . They were authenticated by 31 abbesses. In the 17 th century, two superiors prepared individual files themselves, because we are dealing with the identification of hands thanks to their signatures. On the other hand, there are seven such cases in the next century, and one in the 19th century. In addition, two documents were prepared by a sister who served as a secretary in the first half of the 18th century, and one by a regular nun in 1762 . It should be assumed that the remaining documents came from the hand of public writers, prosecutors of the monastery of the Poor Clares or Franciscans from the nearby Gniezno convent, with which the sisters maintained - as is clear from the records of monastics and provinces - good relations.
\end{abstract}

Keywords: Poor Clares; Gniezno; parchments; diplomas; documentation; archives, inventory 